
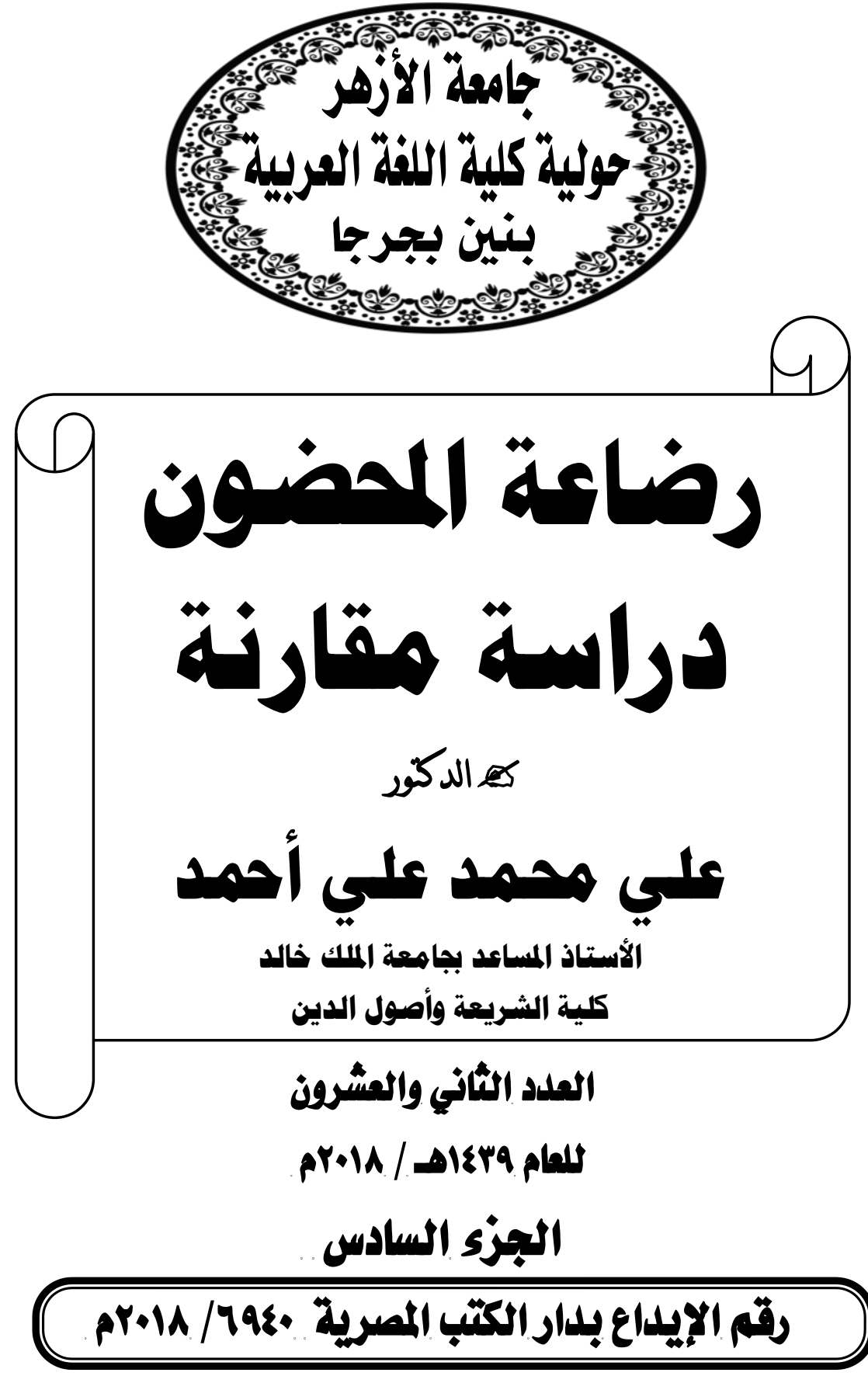

الترقيه الدوله 2356-9050 


\section{رضاعة المحضون دراسة مقارنة}

sin

العدد الثاني والقشروز للعام A. الجزم السادس

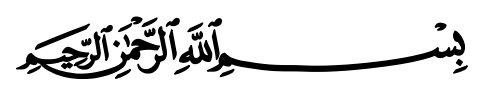

\section{( شكر وتقدير)}

( الباحث يود شكر جامعة

اللاك خالد علي الدعم

الإداري والفني لهذا البحث)

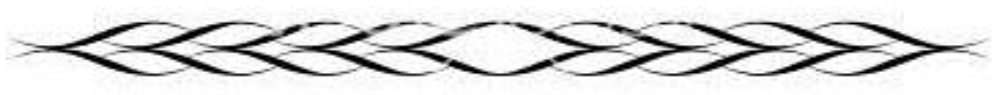




\section{الترقير الدولخ}

ISSN 2356-9050
$077 \%$

حولية كلية اللفة العربية بجرجا

مجلة علمية مجكمة

\section{Abstract}

Breastfeeding is one of the best ways to feed a child because breast milk contains the most essential elements of growth through equal proportions that meet the needs of the child every day from birth to weaning age. It is the easiest and most useful food used by the child since it contains concentrated amounts of Proteins, and substances containing antimicrobials and microbes, and thus transmits additional immunity to the newborn against diseases in order to cooperate with what has been taken from the placenta during pregnancy from disease-resistant substances, and then from a health point of view, infectious and intestinal disorders are rarely present Or breastfeeding mother's breast unlike industrial milk, which is often accompanied by gastrointestinal disorders indicated by the World Health Organization in 1980, which indicated that more than ten million children have died as a result of nonbreastfed from their mothers' reports. In addition, the calories contained in the amount of breast milk is much higher than the milk produced by the caloric calories in the same amount, so the child gets more food and increases the weight quickly, and psychologically, most of the research that the breastfeeding Especially in the first year prefer breast feeding because it strengthens the emotional and social bond between mother and child, the survival of the child attached to his mother's breast during breastfeeding satisfies his emotional and psychological needs and immersed him with a sense of safety and reassurance; Breastfeeding has a great impact in terms of meeting Through the imposition of values, principles, social norms, customs, customs and traditions that enable him in the future of his life to interact socially and sound with different life situations. 


\section{رضاعة المحضون دراسة مقارنة}

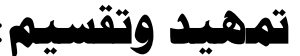

تعتبر الرضاعة الطبيعية من ثذي الأم أفضل الوسائل لتفذيــة الطفــل

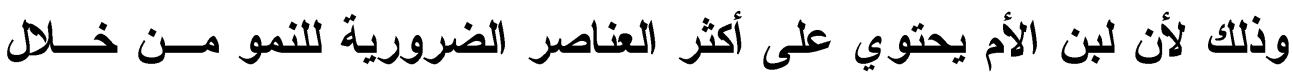

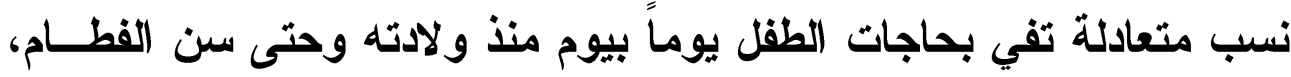

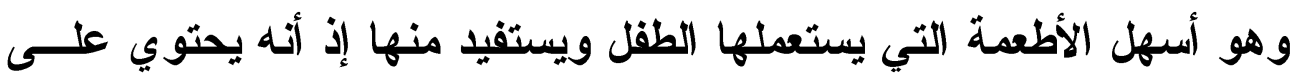
كميات مركزة من البروتينات المهضومة وعلـى المــواد المحتويــة علــى

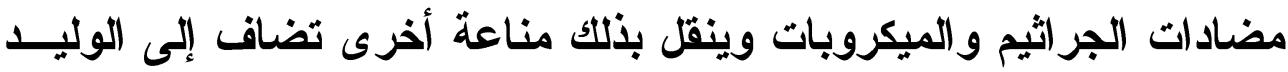

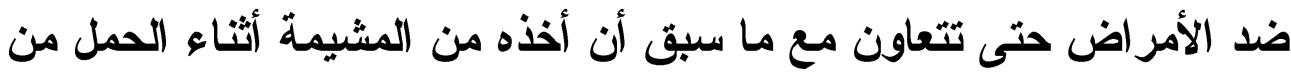

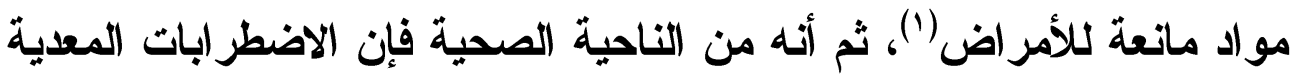

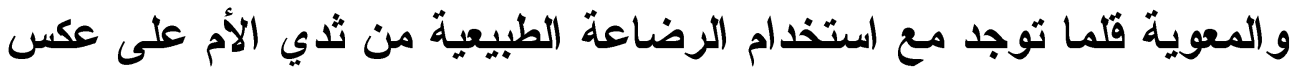

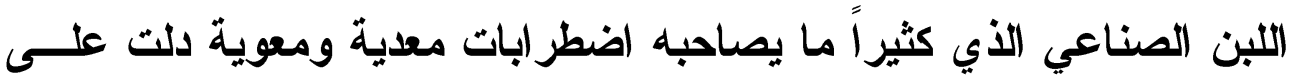

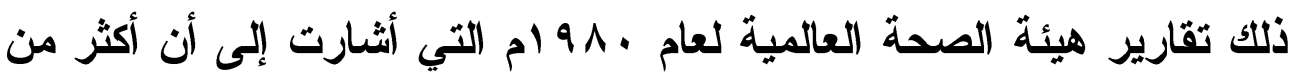

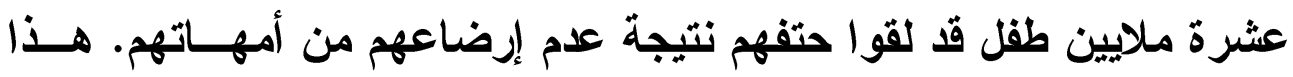

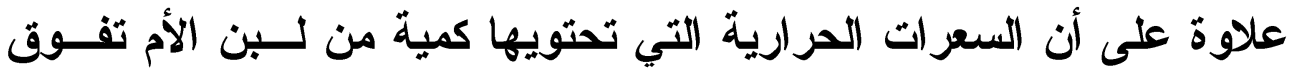

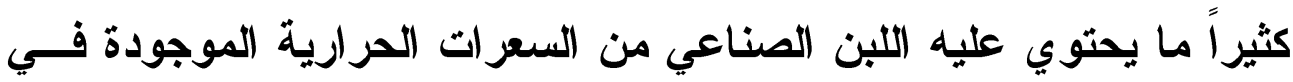
نفس الكمية، لذلك فإن الطفل يحصل على كمية أكبر من الطعام ويزيد وزنه

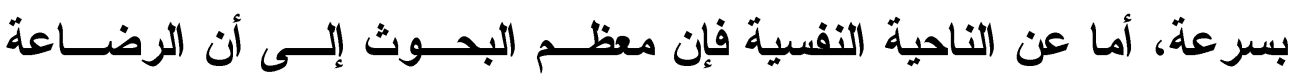

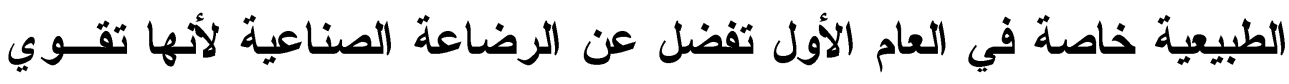

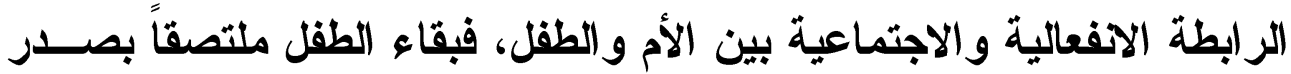

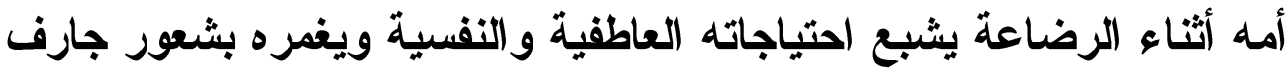


الترقير الدولخ

ISSN 2356-9050
\%. 0975
حولية كلية اللفة العربية بجرجا مجلة علمية محكمة المية

من الأمان والاطمئنان؛ كما أن للرضاعة الطبيعية أثر عظــيم مــن الناحيــة

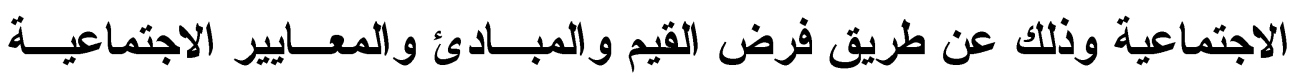

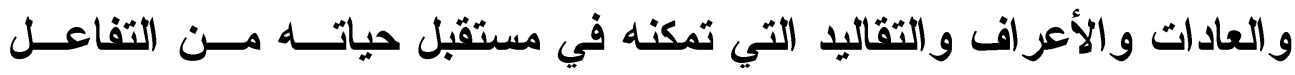

الاجتماعي السليم مع مختلف مواقف الحياة(')

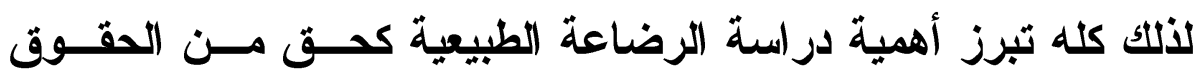
الثرعية للمحضون، وذلك من خلال تعريفها ومدتها ومدى وجوبها على الأم وأحكام الأجرة والظئر وأثر الرضاعة علي النحو الآتي: التمهيد: أهمية الرضاعة. المبحث الأول: في تعريف الرضاعة ومدتها في الفقه الإسلامي والقانون الوضعي. المطاب الأول : تعريف الرضاعة ومدتها في الفقه الإسلاهي والقانون المطاب الثاني : هدى وجوب الرضاع على الأم في الفقه الإسلاهي والقانون

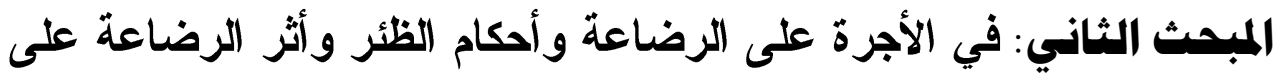
حق الحضانة في الفقه الإسلامي و القانون الوضعي.

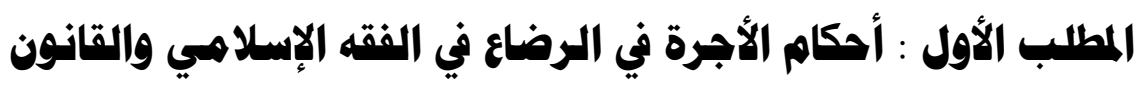

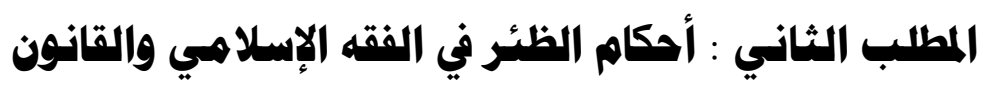

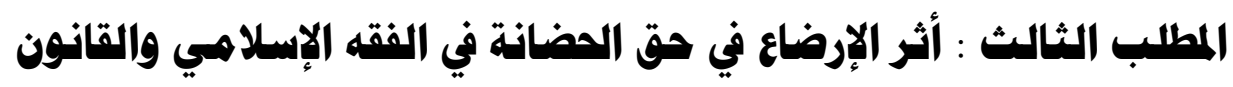
الخاتمة وتتضمن: فهرس المادر والموضوعات 


\section{رضاعة المحضون دراسة مقارنة}

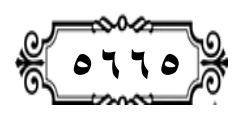

\section{المبحث الأول}

تعريف الرضاعة وهدتها وهدى وجوبها على الأم

$$
\text { في الفقه الإسلاهي والقانون }
$$

\section{المطلب الأول}

تعريف الرضاعة وهدتها في الفقه الإسلاهي والقانون

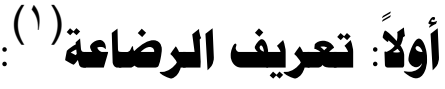

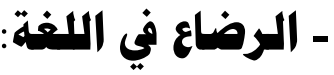

- يطلق لفظ الرضاع لغة على المص، ويراد بالمص وصول اللبن إلى الى الفي

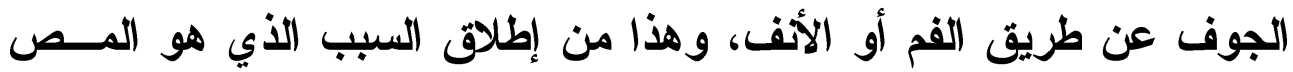

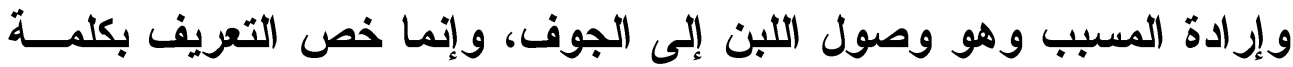

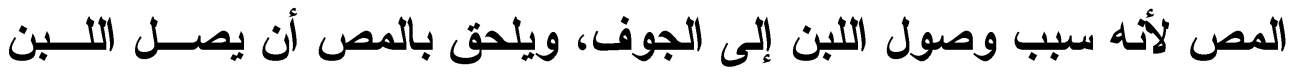
إلى الجوف عن طريق الفم من غير مص أو عن طريق الأنف، والرضــاع:

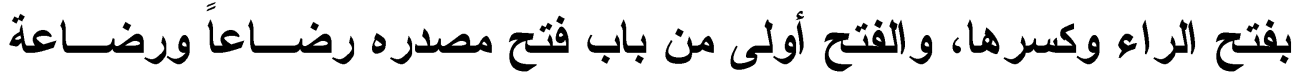

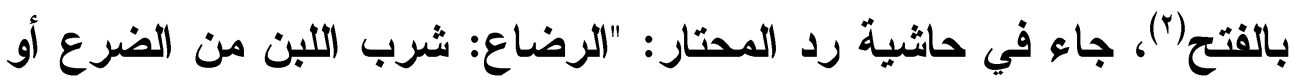

$$
\text { الثي سواء من إنسان أو حيوان"(("). }
$$

(1) عند إطلاق لفظ الرضاعة فإنه يطلق على ما هو سبب في التحريم وعلى ما هو لازم وحق من حقوق المحضون، وهو محل بحثنا.

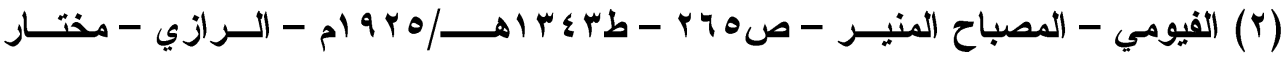

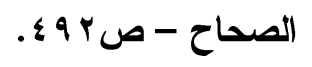

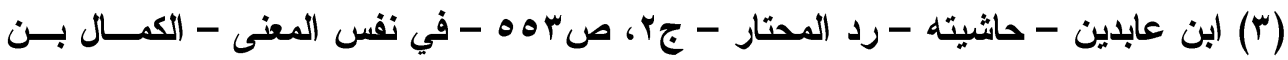

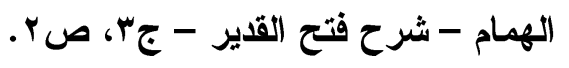


الترقير الدوله ISSN 2356-9050
Q⿻日土𧘇 0777
حولية كلية اللفة العربية بجرجا

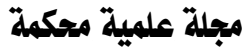

- الرضاع شرعًا: - | (ال

لقد تعددت عبارات فقهاء المذاهب الإسلامية في تعريف الرضاع فهي

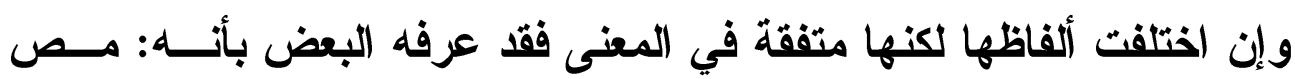

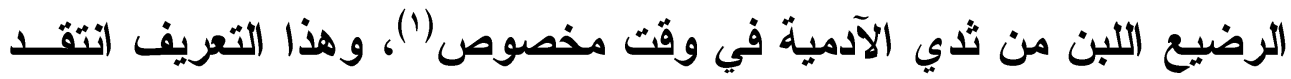

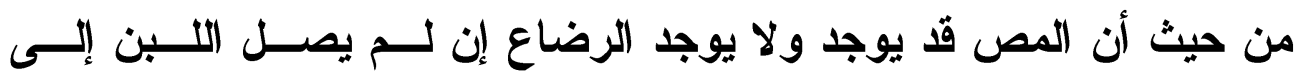
الجوف، وقد يوجد الرضاع ولا يوجد المص كما فـــي وصــول اللـبن إلــى

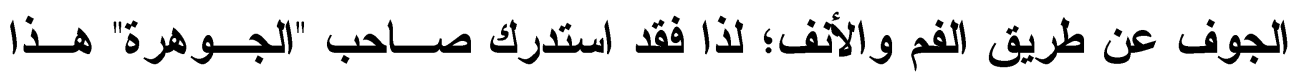
اللبس وعرف الرضاع بأنه: عبارة عن إرضاع مخصوص سواءً وصل اللبن

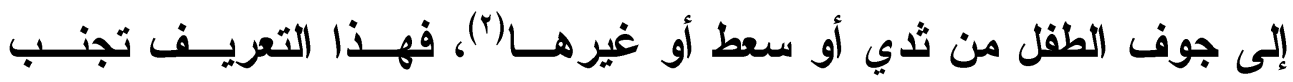

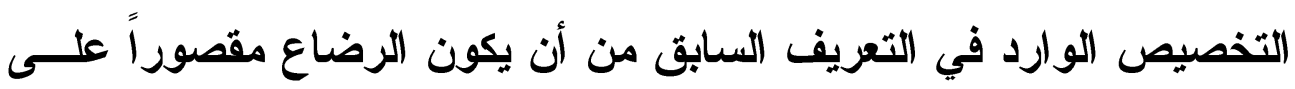

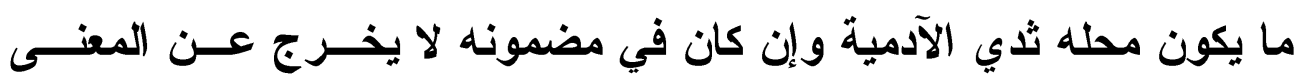
اللغوي للرضاع.

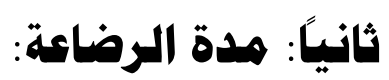

إن التعرض لاراسة هذه المدة يتطلب بيان هذه المدة من حيث لزومها لنمو المحضون، وهن حيث استحقاق الأجرة فيها:

(1) الكمال بن الهمام- شرح فتح القدير - المرجع السابق - نفس الموضع.

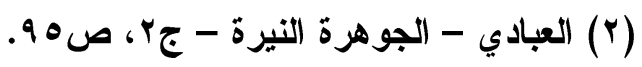

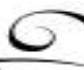




\section{رضاءة المحضوز دراسة مقارنة}

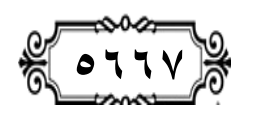

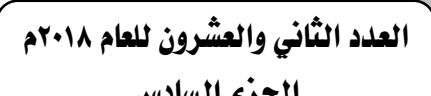
الجزء السادس

\section{أولاً: هدة الرضاعة هن حيث لزوهها لنهمو المضون:}

لقد اختلف فقهاء المذاهب الإسلامية في مدة الرضاعة اللازمة لنمـو

$$
\text { المحضون، ويمكن حصر الخلاف في رأيين: }
$$

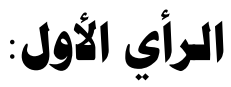

ويرى أن المدة اللازمة لإرضاع المحضون سنتان فقط، وممن ذهـــ

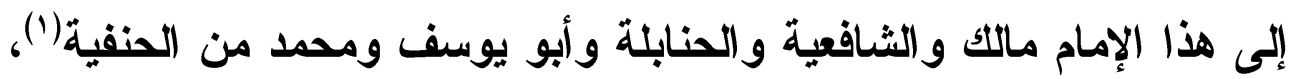

وروي عن مالك أنه رأى الشهر والشهرين فوق الحولين(؟).

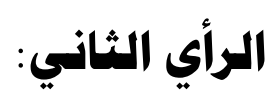

ويرى أن مدة الرضاعة ثلاثون شهراً، وممن ذهب إلى هذا الإمام أبو

حنيفة رحمه الله (ץ).

\section{الأدلــــة}

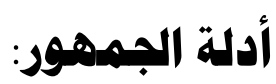

استذل الجمهور على قولهم بأن مدة الرضاعة سنتان بأدلة من الكتاب

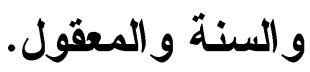

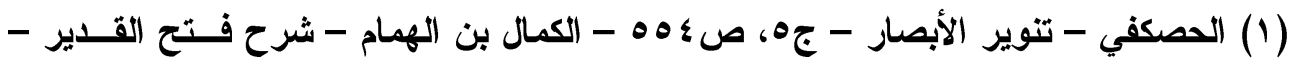

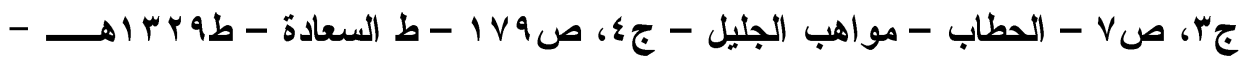

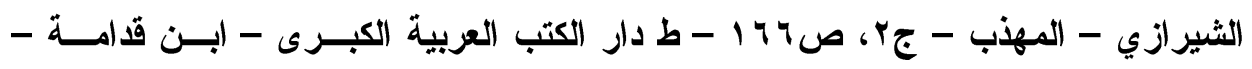

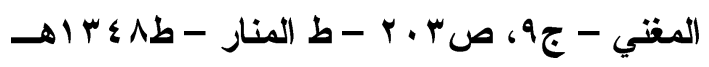

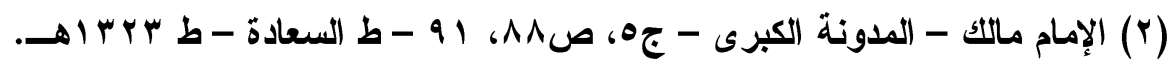

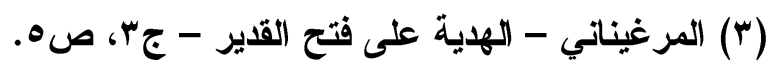




\section{الترقير الدولخ}

ISSN 2356-9050
0,0791
حولية كلية اللفة العربية بجرجا مجية مجلة علمية محكمة المية

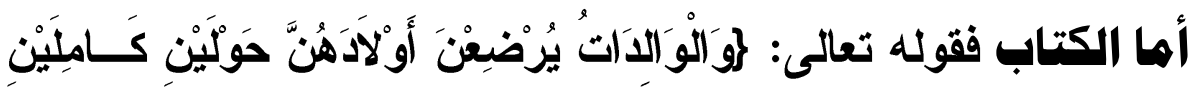

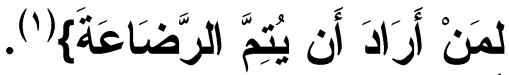

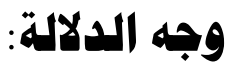

الآية تدل على أنه لا رضاع بعد تمام الحولين فهي مدة الرضاع(").

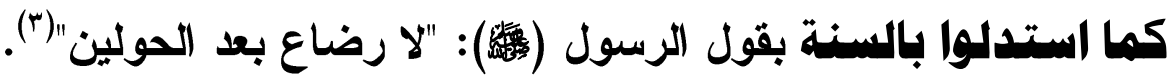

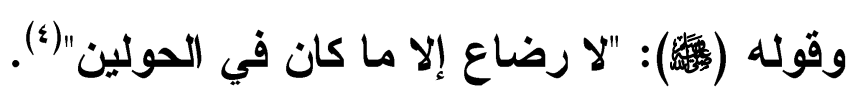

ــ كما استدل الجمهور بالمعقول فقالوا: "إن الثارع لم يحسرم إطعسام

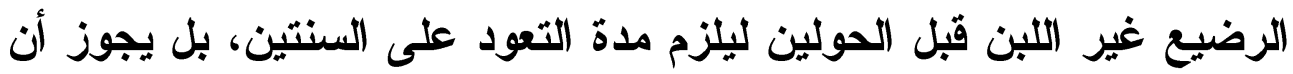

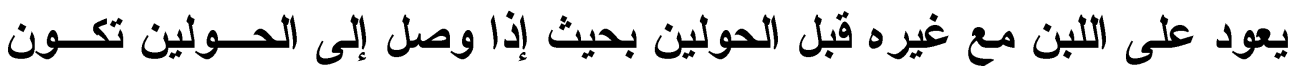

العادة قـ استقرث(•).

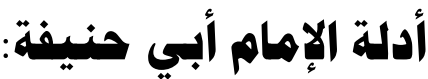

استدال الإمام أبو حنيفة على قوله بأن مدة الرضاعة ثلالتــون شـــهراً

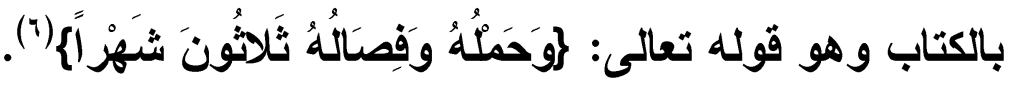

$$
\text { (1) سورة البقرة - الآية rrr (1) }
$$

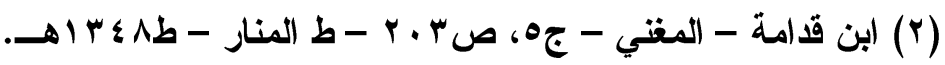

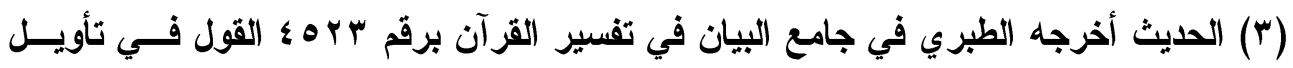

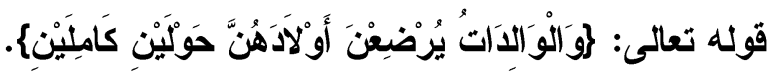

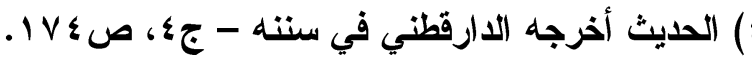

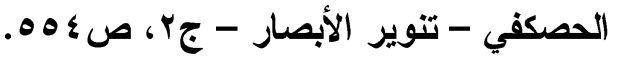

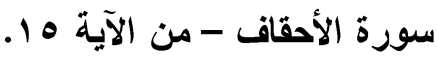




\section{رضاعة المحضوذ دراسة مقارنة}

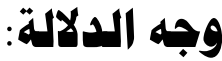

أن المدة في الآية مضروبة لكل من الحمل و الفصال كقول القائل: أحلت الدين الأي على فلان و الدين الأي على فلان ثلاث سنين فإنه يفهم من ذللك أن السنين لكل من الدينين (1).

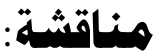

ناقش الجمهور دليل الإمام أبي حنيفة فقالوا: إن الإمام رجع عن قوله

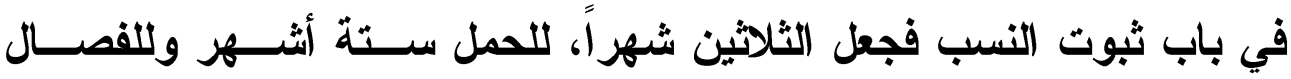

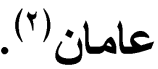

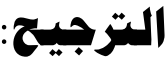

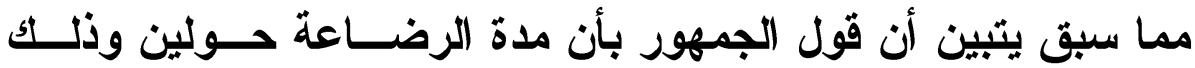

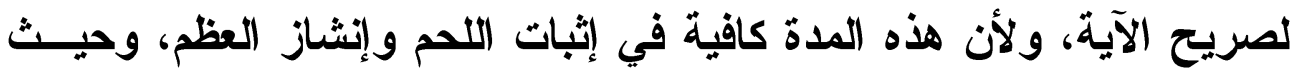
أن الإمام أبي حنيفة قال بذلك في باب ثبوت النسب، كما أنه يحمل النصوص

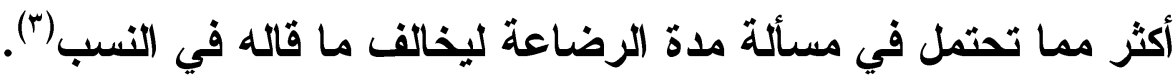

\section{ثانيًا: مدة الرضاعة هن حيث استحقاق الأجرة:}

ـ اتفق الفقهاء على أن مدة الرضاعة في حثى استحقاق الأجرة علــى الأب هي حولين كاملين، فالمطلقة لا تستحق أجر عن الرضاع بعد الحولين.

(1) المرغيناني - الهابة - الموضع السابق.

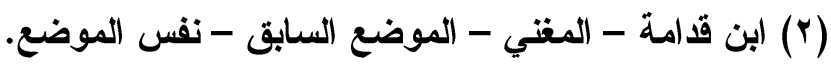
(ז) راجع من يو (افقتا في هذا الترجيح - د. هلالمي عبد اللاه،،د. خالد محمد القاضي - المرجع

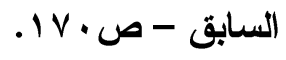




\section{الترقيم الدولخ}

ISSN 2356-9050

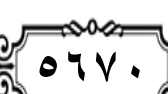

حولية كلية اللفة العربية بجرجا موبمة مجلة علمية محكمة

جاء في حاشية رد المتار: "إن أكثر المشايخ على أن الرضاع في حق

الأجر حولان عند الكل حتى لا تستحق بعد الحولين"((1).

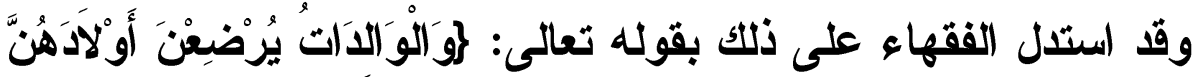

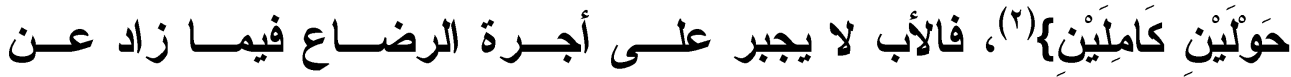

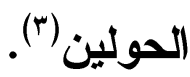

\section{ثالثًا: هدة استحقاق الأجر في القانون:}

أخذ القانون بما قرره جمهور الفقهاء مـن أن مـــة الرضــاع فــي

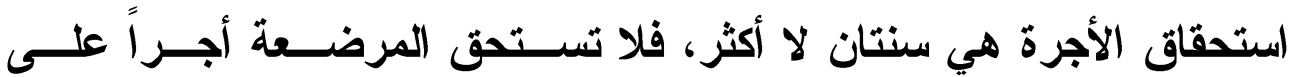

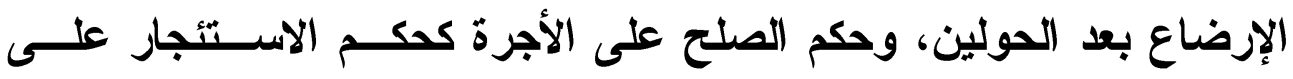
الرضاع، فلا يجوز في حال قيام الزوجية أو في الطلاق الرجعي، ويجوز في الاجي

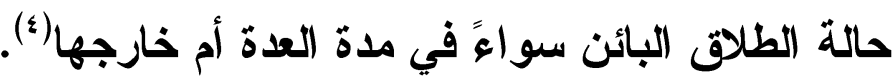

(1) (ابن عابدين - حاثشيته المسماة رد المختار - جr، ص ابr و 9.

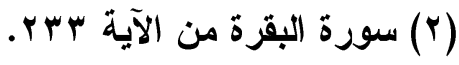

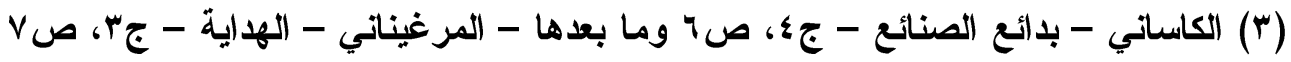

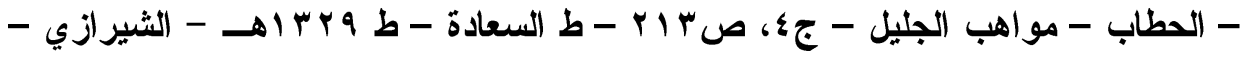

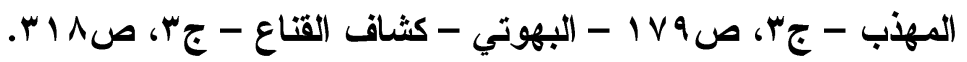

( ع) الثيخ/ أحمد إبراهيم والمستشار واصل علاء - المرجع السابق - ص ع Vه. 


\section{رضاعة المحضون دراسة مقارنة}

क. $07 V_{0}$

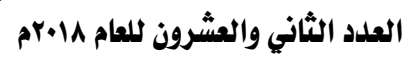
الجزء السادس

\section{المطالب الثاني}

\section{هدى وجوب الرضاع على الأم في الفقه الإسلاهي والقانون}

\section{أولاً: هدى وجوب الرضاع على الأم في الفقه الإسلاهي:}

الأم حالة إرضاع الصغير إما أن تكون في حبال الزوجية وإما أن تكون

مطلقة وفي الحالتين إما أن تكون متعينة أي لا يوجد من يقوم مقامها فــي لـاني

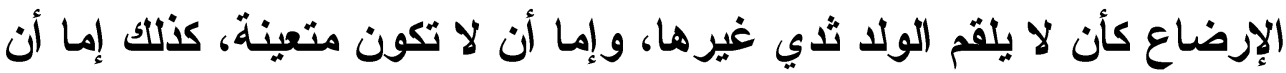

تكون المرأة ممن لم تجر عادة مثلها على إرضاع ولدها، أو تجري العـادة

بإرضاع ولدها، وسوف نتناول بيان أحكام هذه الحالات فيسا يأتي:

الحالة الأولـى وهي أن تكون الأم مطلقـــة وغير متعينـــة

لإرضاع ولدها بأن يستطيع الولا أن يلقم أي ثدي أو أن يكون للأب أو

للمحضون مال يستطيع الإنفاق عليه أو على نفسه بشر اء اللبن أو إحضــار

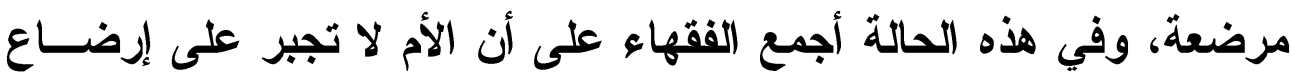

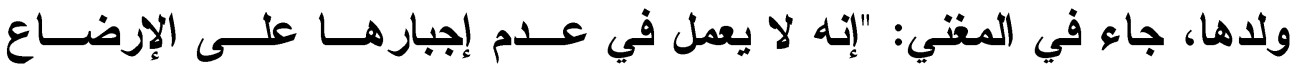
خلاف"(')، وعللوا ذلك بأن الرضاعة من النفقة، والنفقة على الأب وحده(؟). الحالة الثانيسة: وهي أن تكون الأم مطلقة في غير حبــال الزوجيـة، ولكنها متعينة للإرضاع بأن كان الولا لا يلقم ثدي غيرها أو لم يكن للأب أو لو

$$
\text { (1) (بن قدامة - المغني - جوج، صبr اسب. }
$$

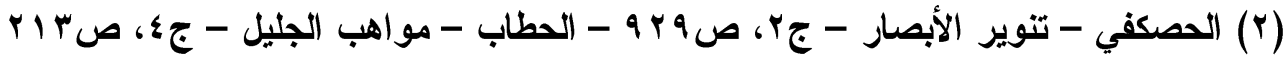
- ابن قدامة - المغني - المرجع السابق - نفس الموضع. 


\section{الترقير الدولخ}

ISSN 2356-9050
Q. 07 V V
حولية كلية اللفة العربية بجرجا

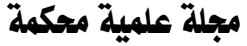

للمحضون مال أو لا يجد الأب من ترضع الولد، فقي هذه الحالات وأمثالهــا

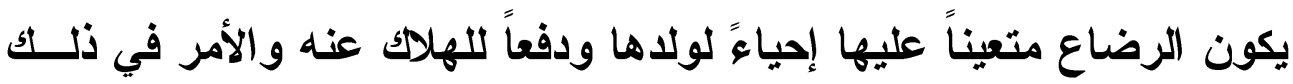
ياخل حيز الضرورة التي تبيح المحظور (').

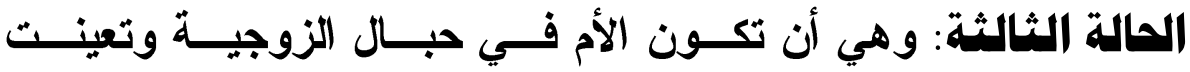
للإرضـــاع، وقد اتفــق الفقهاء أيضاً على إجبار الأم بإرضاع ولدها. جاء في حاشية رد المتــار: "إن الإجبار على الإرضاع في مثــل هـــه الحالات هو الأصح وأن عليه الفتوى، وقال في الفتح: أنه هو الأصوب"((†). الحالة الرابعـة: وهي أن تكون الأم في حبال الزوجيــة ولـــــت تـــين للإرضاع، وقد اختلف الفقهاء في حكم إجبارها على الإرضاع، ويهكن حصر الخلاف في قوالين: - ان

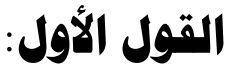

ذهب البمهور هن الهنفية والشافعية والهنابــة إلى أن الإرضاع ليس واجباً عليها، فلا يكون للزوج أن يجبرها على القيام به قضـــاءً لكنــهـ

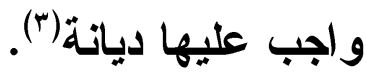

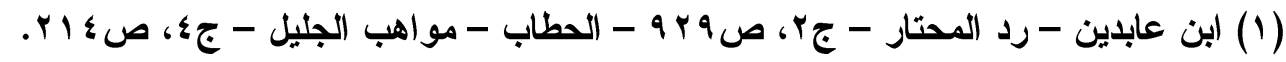

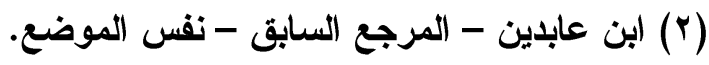

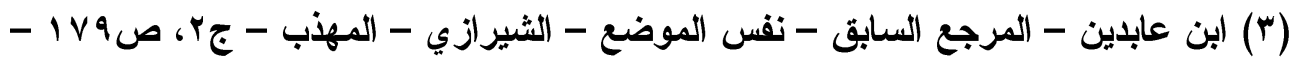

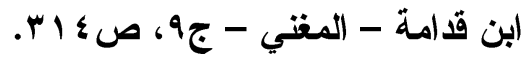




\section{رضاءة المحضوز دراسة مقارنة}

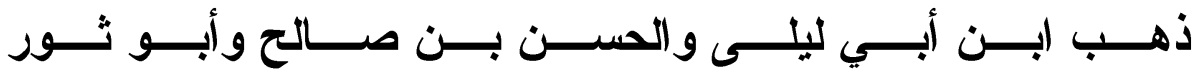

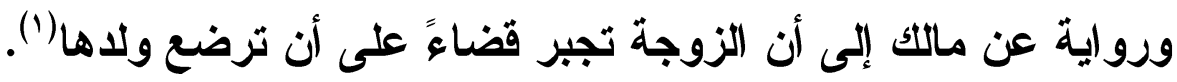

\section{الأدلــة}

أدلة البهمهور:

استلال الجمهور على قولهم بعدم الإجبار قضاءً بالكتاب وهو قولــهـ

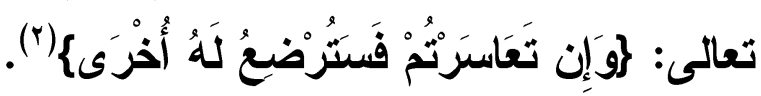

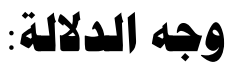

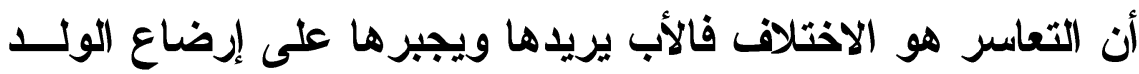

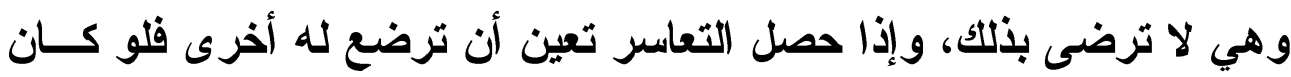

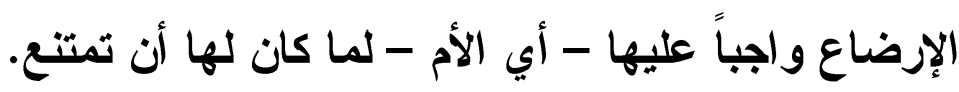

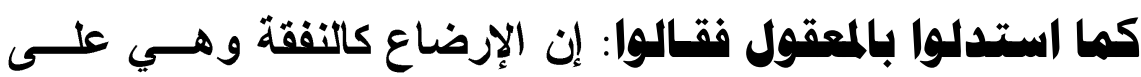
الأب ومن البليهي أن من لم تجبر على النفقة لا تجبر على الإرضاع(").

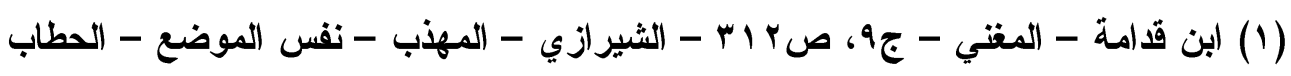

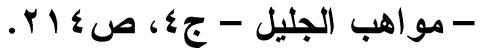

$$
\begin{aligned}
& \text { (r) سورة الطلاق - من الآية جاء }
\end{aligned}
$$

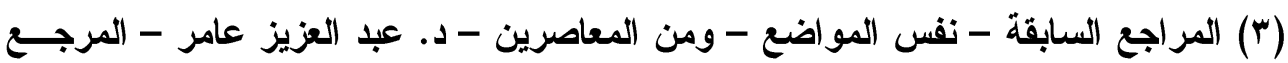

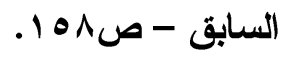




\section{الترقير الدولم ISSN 2356-9050}

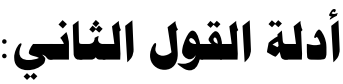

استثل القائلون بإجبار الأم قضاء على إرضاع ولاهـا بالكتاب وهــو

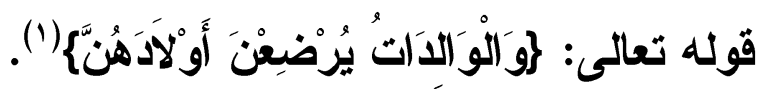

وجه الدلالة:

أن الآية خبرية مفهومة من مفهوم الأمر . وهذا الأمر يفيد الإجبـار

قضاءً إذا (متنعت عن الإرضاع(؟).

التزجيح:

- و إني أميل إلى ترجيح القول بأن الأم لا تجبر على الإرضــاع إلا

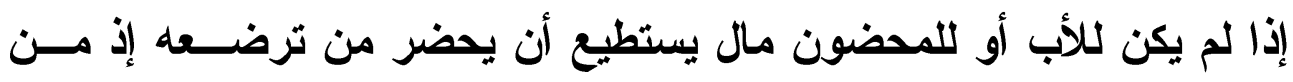

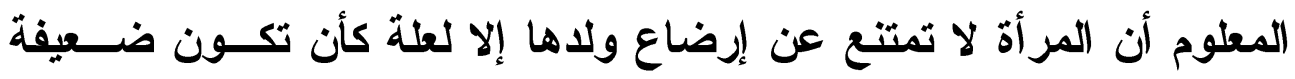
البنية بحيث يؤثر الإرضاع فيها تأثيراً بالغاً.

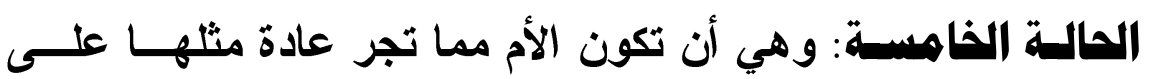

الإرضاع فإنها تجبر على إرضاع ولاها، ولا يسقط هذا الإيجاب إلا إذا كــان

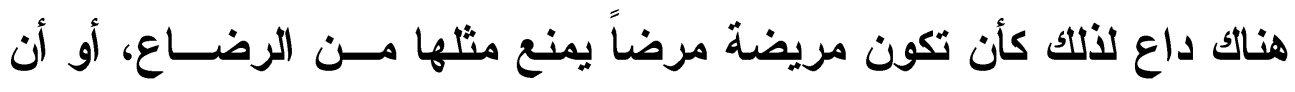
يكون لبنها مقطوعاً.

(1) سورة البقرة - من الآية سبr (1)

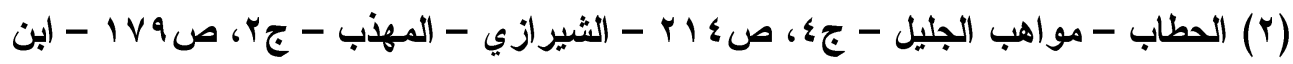

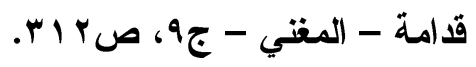




\section{رضاعة المحضون دراسة مقارنة}

الحالـة السادسبة: وهي أن تكون الأم ما لم تجر عادة مثلها علــى

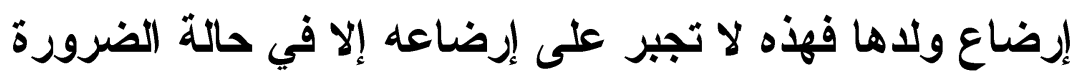

وقد استتد هذا الرأي في الحالتين على العرف والعـادة، لأن منــاط

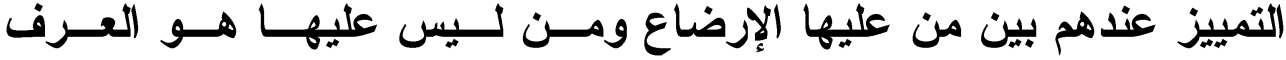

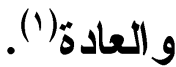

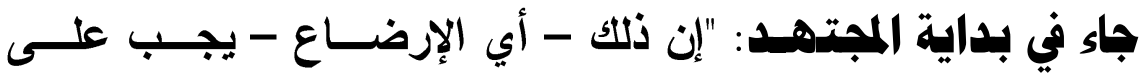

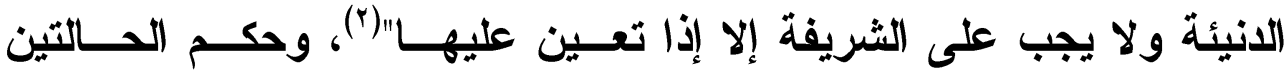

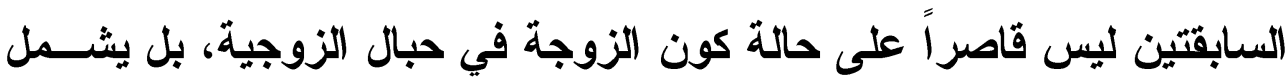
المطلقة أيضاً وسند هذا القول المعقول هن عدة وجوه هي: 1 - أن النفقة على الأب لا يشاركه فيها أحد، ويدخل فــي النفقـــة الإرضاع فعليه مؤنته، فإن قبلت الأم أن ترضع الولد فيها ونعمت، وإن أبت البت فعليه أن يسترضع أخرى. r- كما أن في إجبار الأم على إرضاع ولاها وهي كارهــة. فيـــه

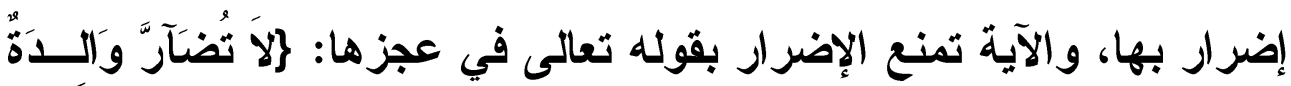

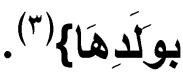

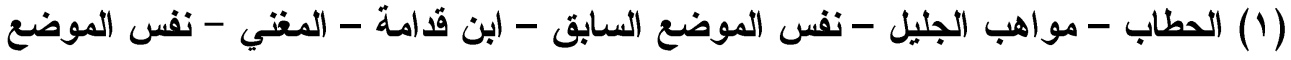

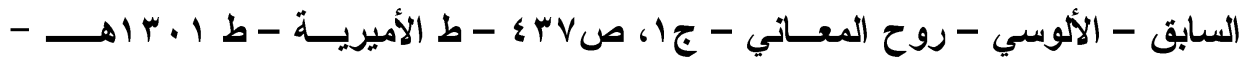

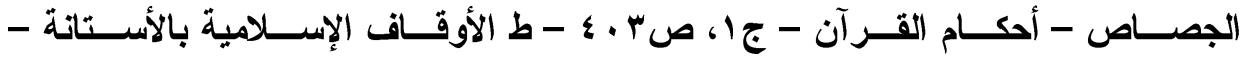

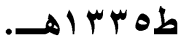

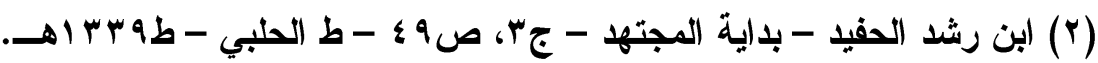

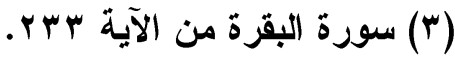

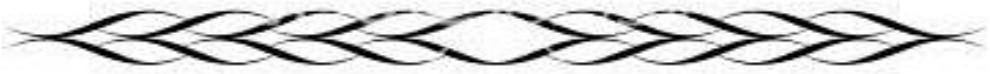




\section{الترقير الدولخ \\ ISSN 2356-9050}

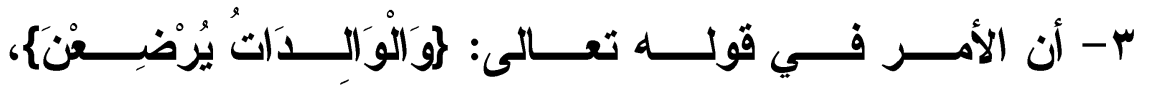

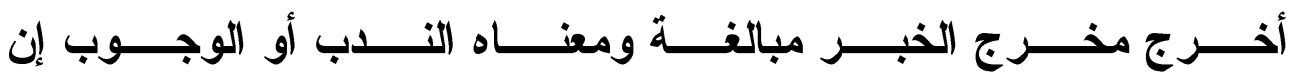

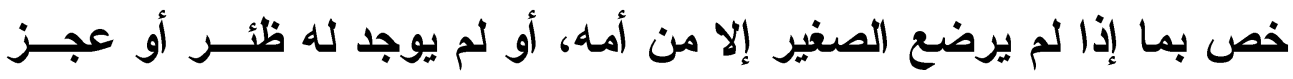

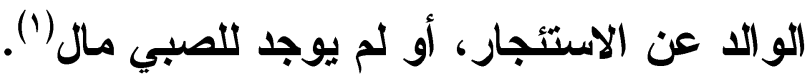

\section{ثانيًا: هدى وجوب الرضاعة على الأم في القانون:}

يفهم من نصوص مشروع القانون العربي الموحد أنه يوافق الفقـــه

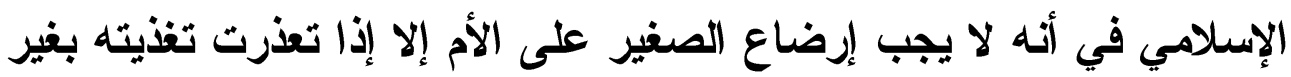

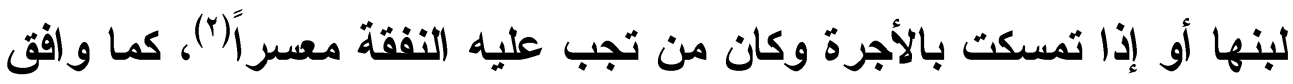

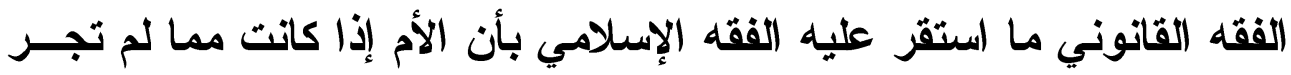

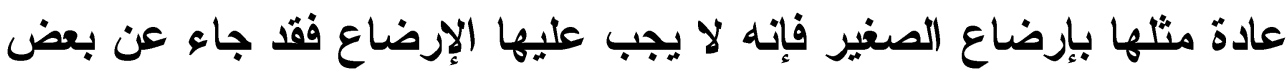

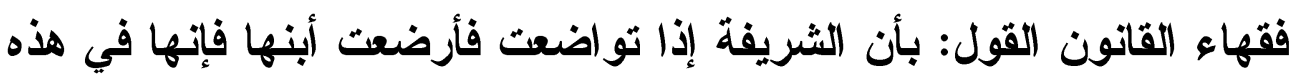

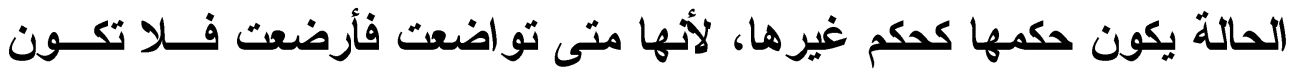

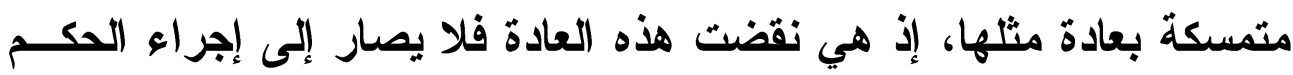

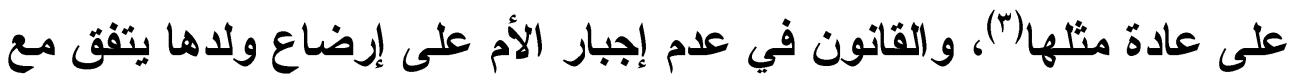

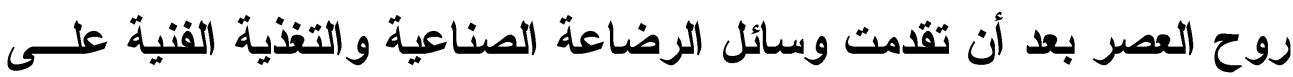

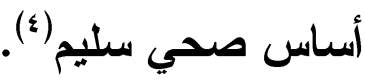

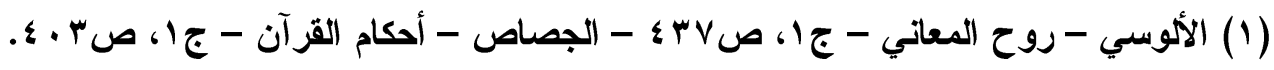

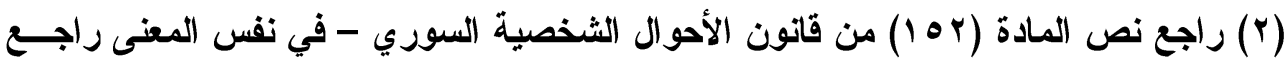

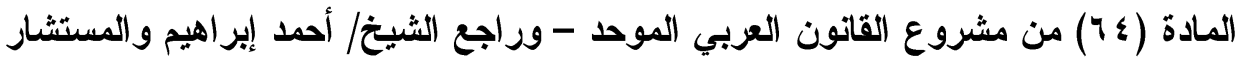

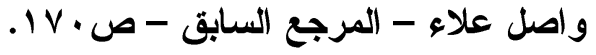

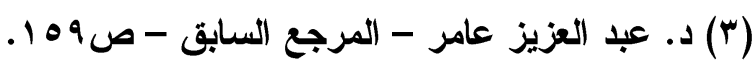

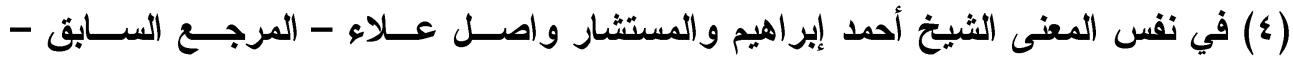
صY ص

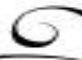




\section{رضاعة المحضوز دراسة مقارنة}

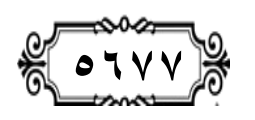

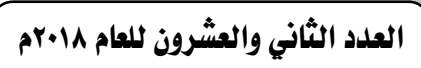

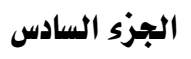

\section{ثالثًا: هدى وجوب الرضاعة للأم في الفقه الإسلاهي والقانون:}

إذا أرادت الأم إرضاع ولاها، فهل يحق للزوج أن يمنعها من ذلــــ

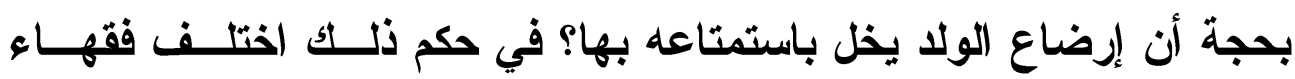

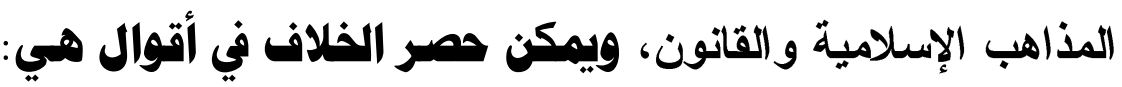

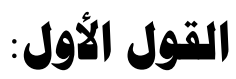

ويرى أن للزوج أن يمنع الأم من إرضاع الولا لأنه يخل باستمتاعه

بها فأثبه ما لو كان الولا من غيره(')

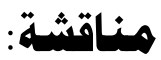

ناقش القائلون بعدم جواز المنع هذا الاليل فقالوا: إن الإرضــاع لا

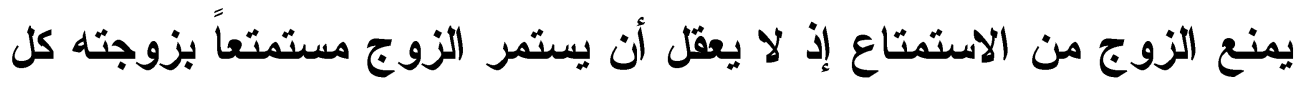

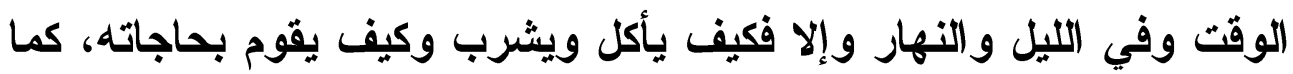

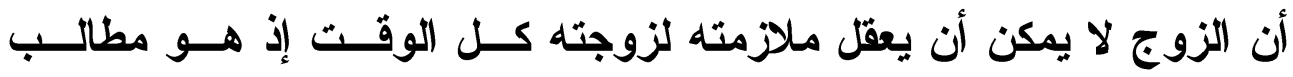

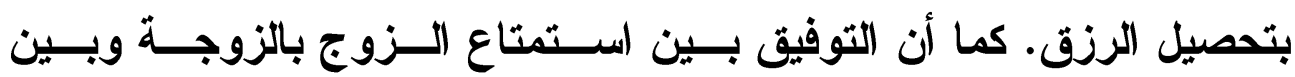

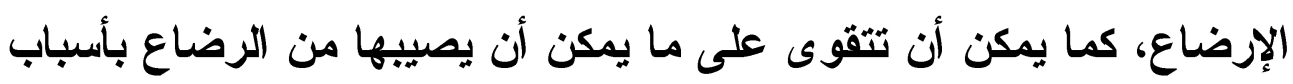

التقوية) (r)

(1) ابن قدامة - المغني - جه، ص الب - ومن فقهاء القانون - د. عبد العزيـز عـامر -

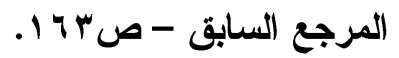

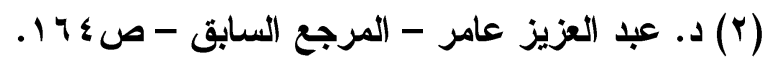


الترقير الدوله

ISSN 2356-9050

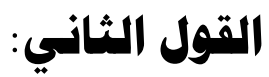

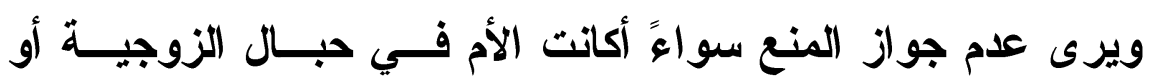

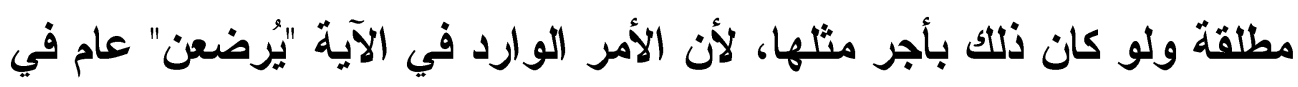

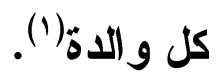

\section{القول الثالث:}

ويرى أن الزوجة إذا أرادت إرضاع ولدها من زوجها، فإنه يكره أن

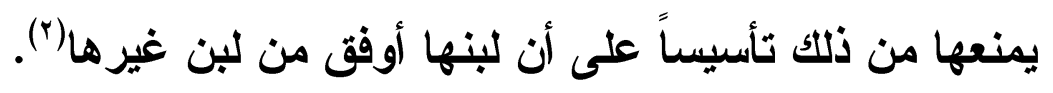

التزجيجح:

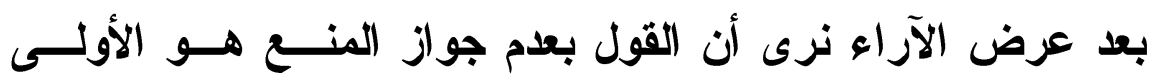

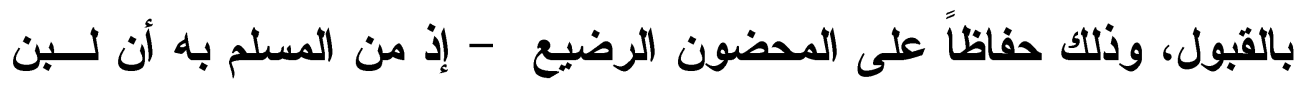

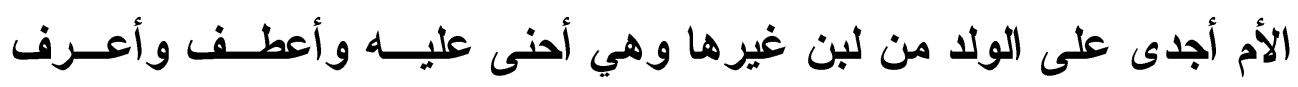

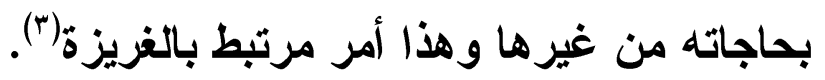

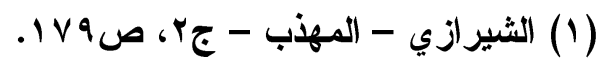

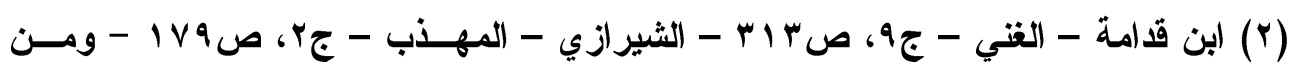

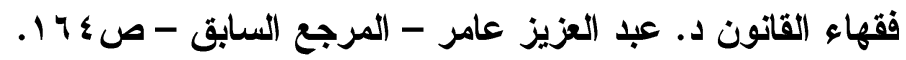

(ץ) راجع من يواققتا في هذا الترجيح - د. عبد العزيز - المرجع السابق - نفس الموضع. 


\section{رضاعة المحضوذ دراسة مقارنة}

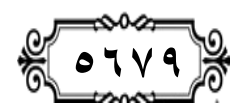

المبحث الثاني

أحكام الأجرة والظئر في الرضاع وأثر الرضاعة على هق الهضانة في الفقه الإسلاهي والقانون

\section{الإطبا الأول}

أحكام الأجرة في الرضاع في الفقه الإسلاهي والقانون

أولاً: أحكام الأجرة في الرضاع في الفقه الإسلاهي:

لا تخلو الأم التي يناط بها إرضاع المحضون، وقد قامت بالإرضــاع

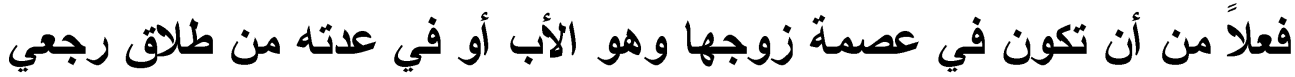

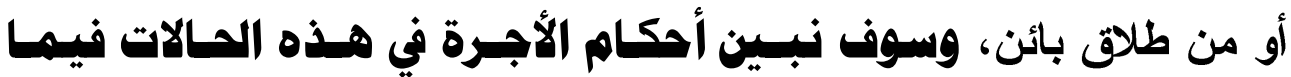

يلي:

الحالة الأولى: حكم أجـرة الأم على الإرضساع حسال قيسام الزوجيسة أو في

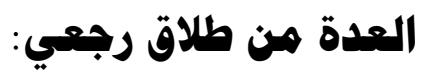

وفي حكم هذه الحالة اختلف فقهاء المــذاهب الإســلامية، ويمكـن

هصر الخلاف في رأيسن:

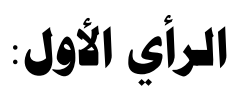

ويرى عدم جواز استئجار أم الصغير لإرضاعه إذا كاتت زوجة لأبيه

أو معتدة له من طلاق رجعي، فإن أرضعت فإنها لا تستحق الأجرة. 


\section{الترقيم الدولخ}

ISSN 2356-9050
D. 071 .

حولية كلية اللفة العربية بجرجا مجلة علمية محكمة

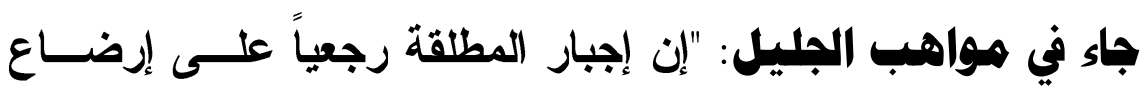

ولاها بغير أجر حال العدة هو المذهب"(!)

وممن ذهب إلى هذا الـــرأي الجمهــور مسن الحنفيــة و المالكيــة

و الثافعية في وجه وبعض المعاصرين(؟).

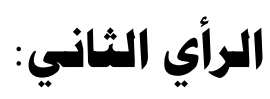

ويرى جواز استثجار أم الصغير على الإرضاع، ومن ثُم يجوز لهــا

أخذ الأجرة وممن ذهب إلى هذا الثافعية في وجه والحنابلة المان.

الأدلـــة

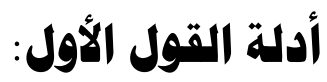

استال القائلون بعدم جواز استئجار الأم على إرضاع الصغير وأنها إذا أرضعت لا تستحق الأجرة بالمعقول هن وجوه:

أولها: إن الإرضاع واجب على الأم ديانة بآية والو الادات، ولا أجرة

على فعل الو اجب عليها.

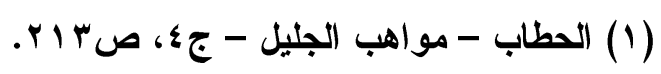

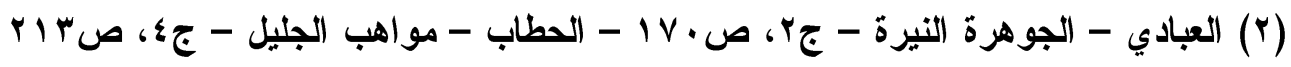

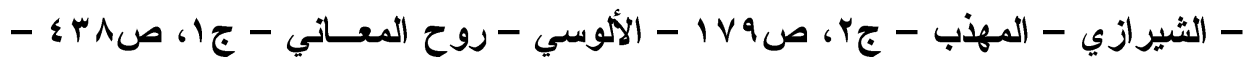

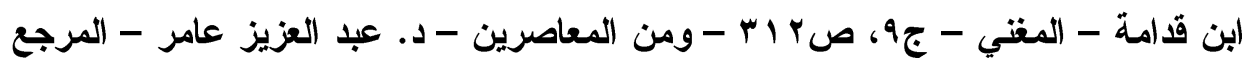

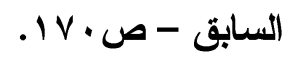

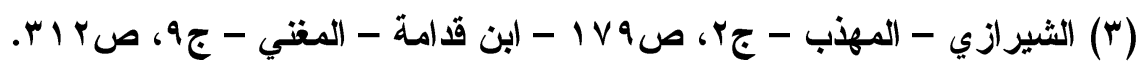




\section{رضاءة المحضوز دراسة مقارنة}

ثانيهـا: أن وجوب الإرضاع عليها في الآية الكريمة مقيد بإيجـاب

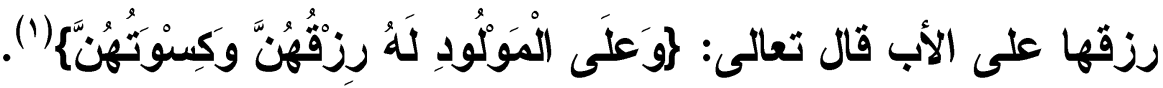

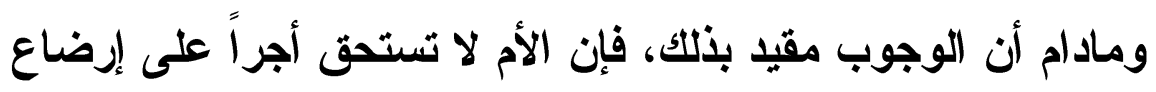

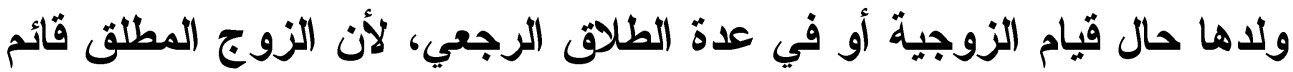
يرزق زوجته أو مطلقته وبكسوتها.

جاء في رد المتار: "فلا يلزم بأجرة الرضاع حتى لا تجتمع عليه في

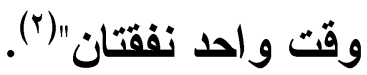

ثالثها: أن الوقت الأي يضيع فيه الإرضاع ملك للأب وهو الــزوج

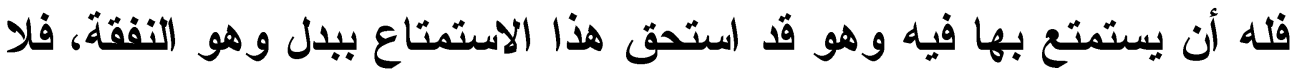

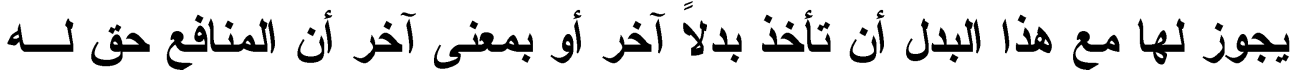
ولا يسوغ أن يستأجر منها ما هو أو بعضه حقاً لها (r).

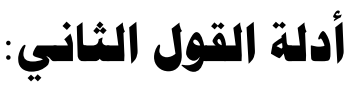

استدال القائلون بجواز استئجار الأم على إرضاع ولادها حـال قيــام الزوجية أو في عدة الطلاق الرجعي بالقياس من عدة وجوه منها: 1 - أن المرأة تستحق الأجر على الرضاع بعد أن تبين من زوجهــا

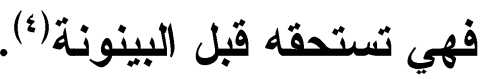

(1) سورة البقرة - من الآية rrr.

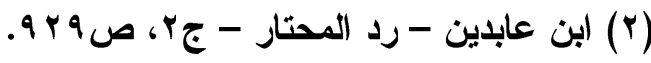

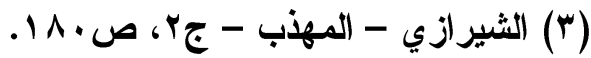

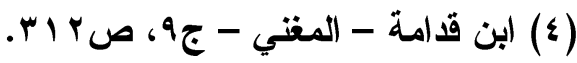




\section{الترقيم الدولم \\ ISSN 2356-9050}

ناقش المانعون لأخذ الأجرة قياس المبيحين فقــالوا: قيــاس أخــــ

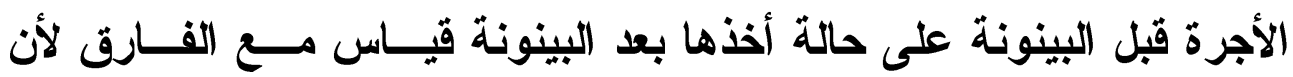
الزوجة بعد البينونة تصير أجنبية عن والا المحضون، وينقطع إنفاقه عليها، فلا يمكن عقلاً قياس حالتها بعد البينونة على حالتها قبلها لهنها. r- كما استالوا بالقياس فقالوا: إن الإرضاع لا يعــو أن يكــون

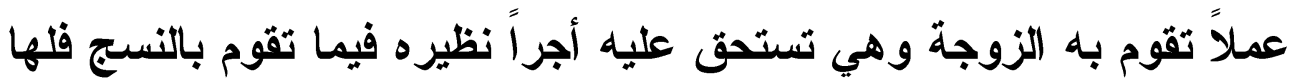

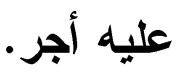

r- إن الإرضاع بالأجر عقد إجارة يجوز للزوجة أن تباثــره مــع غير الزوج إذا رضي الزوج بذلك،، فجاز من الزوج مثل ذلتك أن تؤجر نفسها

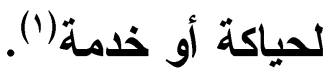

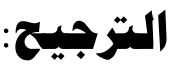

نرى أن القول بعدم جواز الاستئجار هو الأولى بالقبول، لأن المرأة

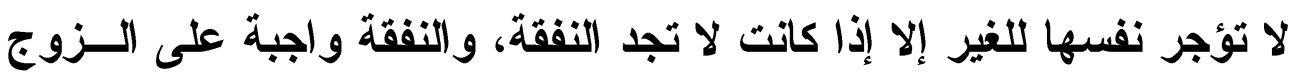

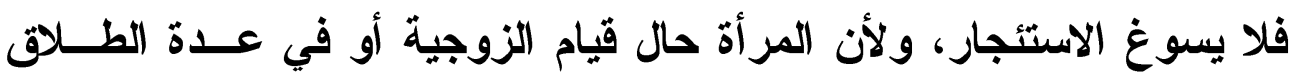

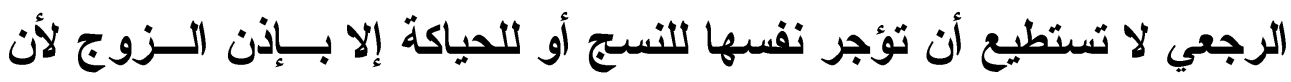

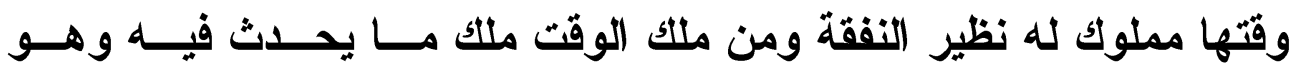
الإرضاع ومن ملك الإرضاع لا يجوز لله استئجاره.

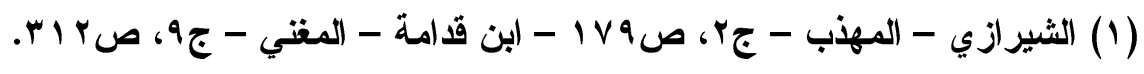




\section{رضاعة المحضون دراسة مقارنة}

\section{الحالة الثانية: هكم أجرة الأم على الإرضاع حالة الطلاق البائن:}

لقد اختلف فقهاء المذاهب الإسدلامية في حكم هذه المسألة، ويمكين

هصر الخلاف في قوإين:

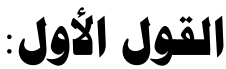

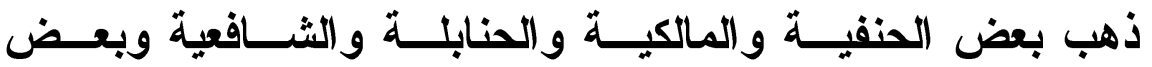

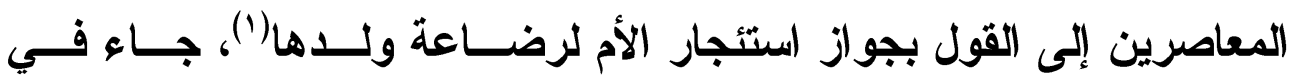
الجوهرة: "وأما المعتدة من البائن فقيه روايتــان والصـــيح منهمــا: أنـــه

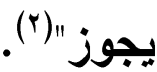

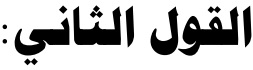

ذهب بعض الحنفية وبعض المعاصرين إلــى القــول بعـــم جـواز

الاستئجار، وأن الأم إذا أرضعت ولاها بعد البينونة لا تستحق الأجرة(").

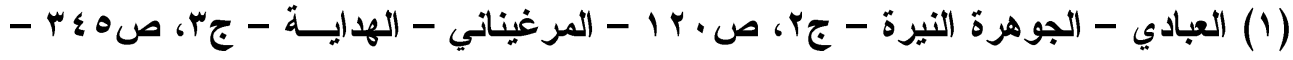

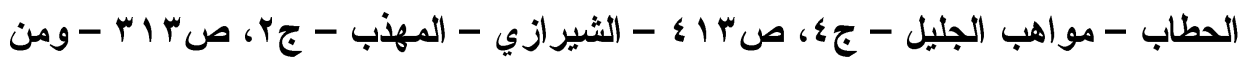

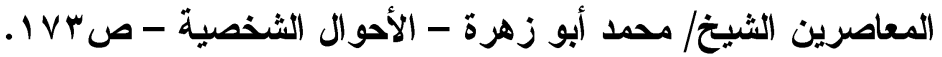

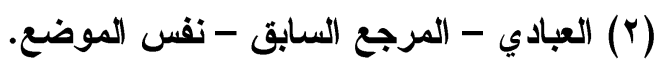

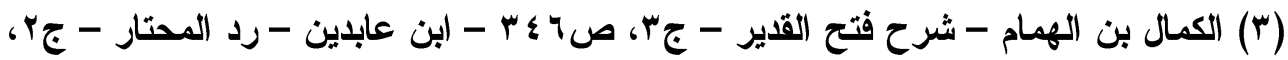
ص • ب9 - ومن المعاصرين - د. عبد العزيز عامر - المرجع السابق - صبr VY. 


\section{الترقيه الدولم \\ ISSN 2356-9050}

\section{الأدرـــة}

أدلة الجمهور:

استثل القائلون بجواز الاستئجار بالمعقول فقالوا: إن البائنة لا ينفق

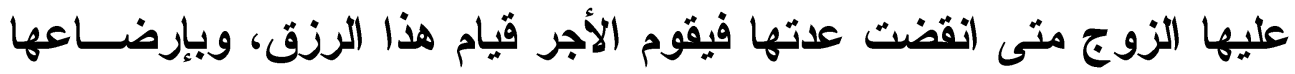

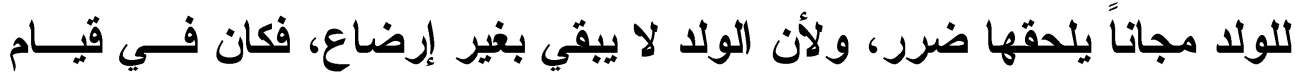

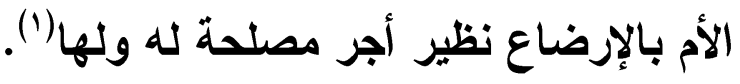

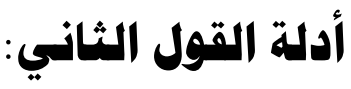

استـل القائلون بعدم جواز استئجار الأم لإرضاع ولـــها وأنهـــا إذا

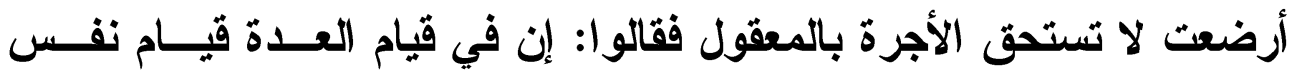

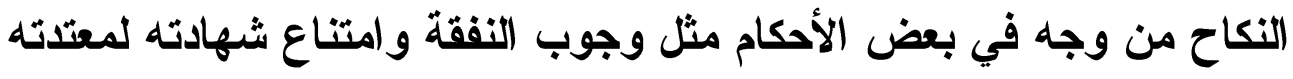

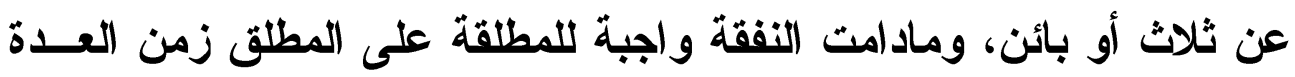

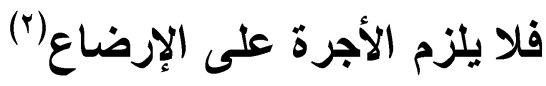

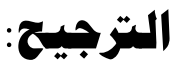

بعد عرض الآراء وأدلتهم فإنـي أميـلـل إلى ترجيح القــول بجــواز

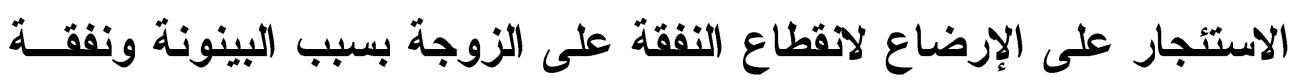

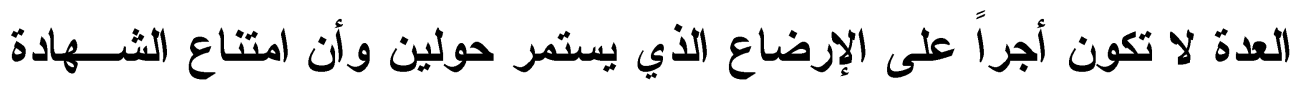

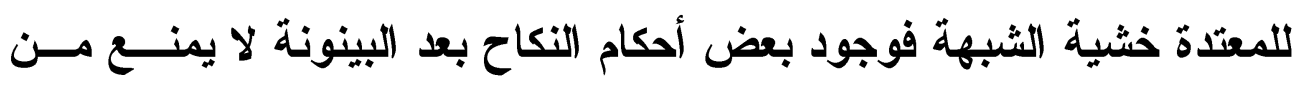

(1) المراجع السابقة المشار إليها في هامش 1.

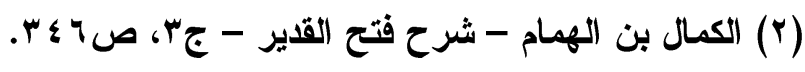




\section{رضاعة المحضوز دراسة مقارنة}

استحقاق الأم للأجرة عن الإرضاع لانقطاع الصلة بينها وبين والد المحضون

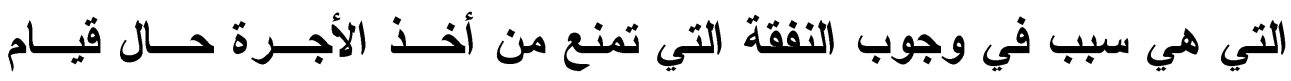

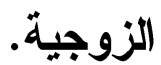

\section{ثانيًا: أحكام الأجرة في الرضاع في القانون:}

يفهم من النصوص القانونية أن القانون سوى في عدم اســـحقاق

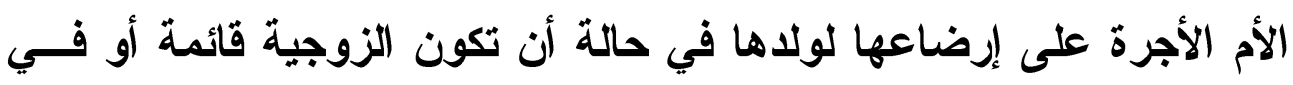

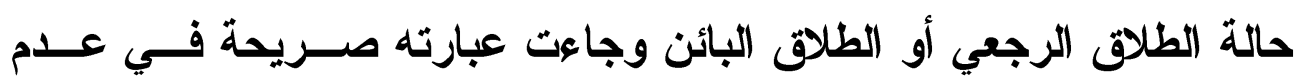

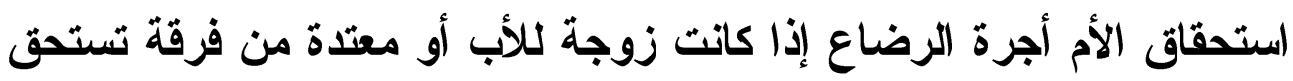

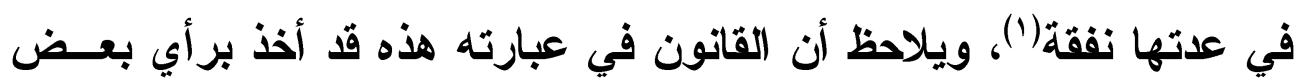

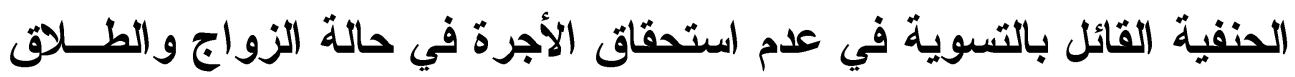

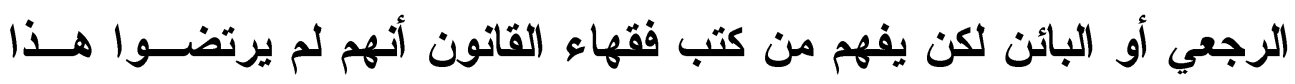
التعميم وقالوا: أنه يجوز استئجار الأم على الإرضاع في حالة الطلاق البهاء البائن

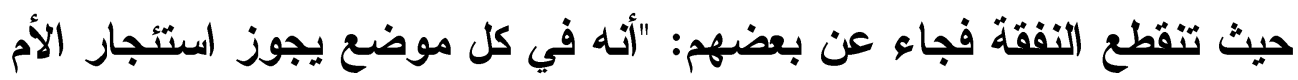

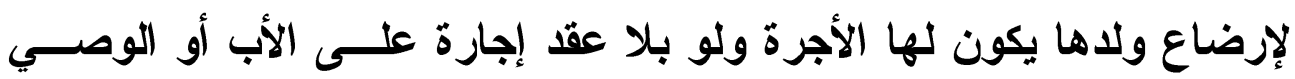

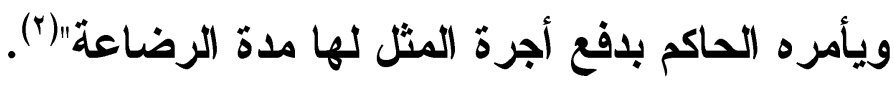

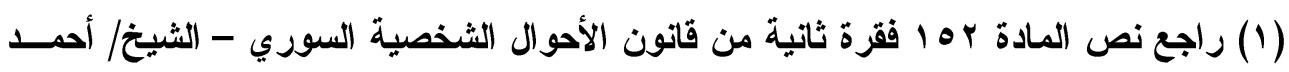

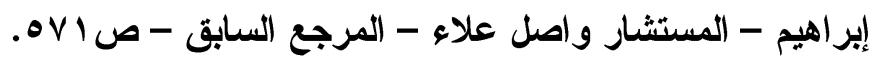

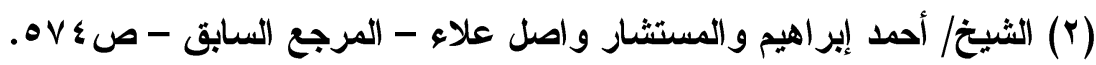




\section{الترقيم الدوله \\ ISSN 2356-9050}

\section{الاطبب الثازي \\ أحكام الظئر في الفقه الإسلالهي والقانون \\ أولاً: أهكام الظئُ في الفقهه الإسلالهي:}

الظئر هي المر أة التي تستأجر لإرضاع الصغير (')، وأحكام إجارتهــا تختلف بحالة أن تكون متزوجة أو غير متزوجة، وكذلك تختلــف بحالــة أن الن يكون عقد الإجارة قبل الزواج أو بعده.

فإن كانت غير متزوجة فهي تملك إجــارة نفســها للإزضــاع دون معقب، وإن كاتت متزوجة وكان عقد الإجارة قبل الزواج أو كان بعد الزواج وأذن الزوج، صع عقد الاستئجار ولزم حتى مضي المدة المتعاقد عليها ولا يملك الزوج فستخ هذه الإجارة، لان منافعها ملكت بعقد سابق على الــزواج، وللزوج في هذه الحالة أن يستمتع بزوجته إذا نام الصــغير أو إذا اثــتخل بغيرها، وذلك لأن وطء الزوج زوجته مستحق بعقد الزواج(؟). وإن كان عقد الاسترضاع بعد الزواج ولم يأذن الزوج لـــ يصــح العقد، لأنه يتضمن تفويت حق زوجها عليها في الاستمتاع، أو أن يختل هذا الاستمتاع، فإذا انقضت المدة ليس عليها أن ترضع الصــبي إلا إذا تعينـــ لذلك بأن كان لا يلقم ثدي غيرها ويكون لها أجر المثل(؟).

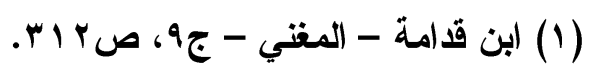

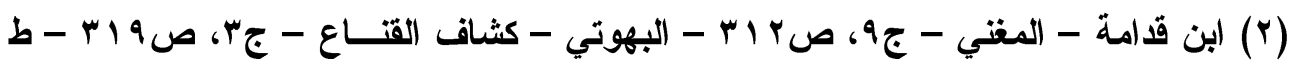

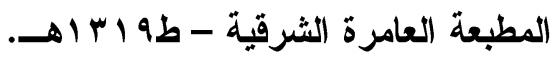

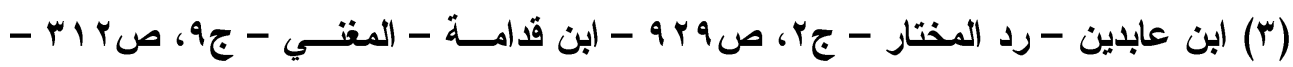

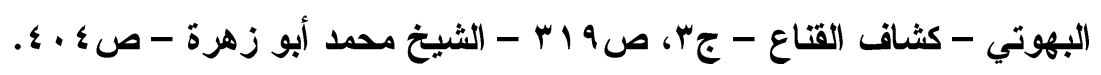




\section{رضاعة المحضون دراسة مقارنة}

الظئر هي العاطفة على ولد غيرها المرضعة له، سواءً أكسانت من

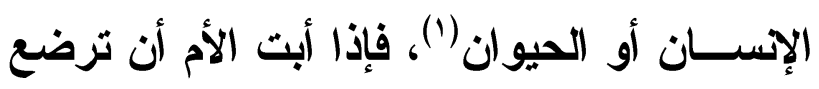

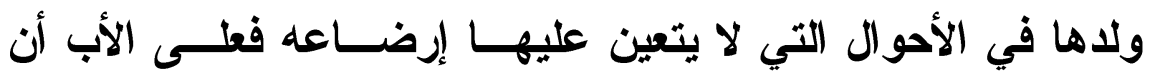

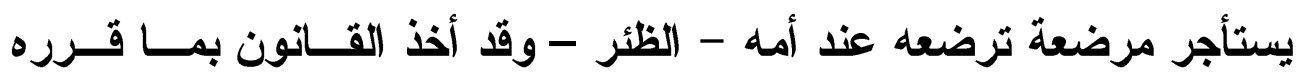

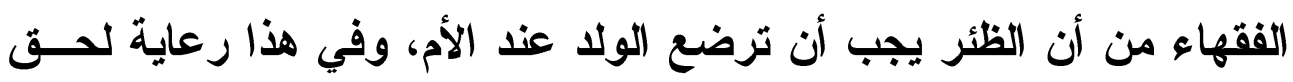

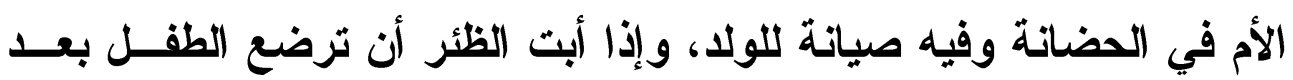

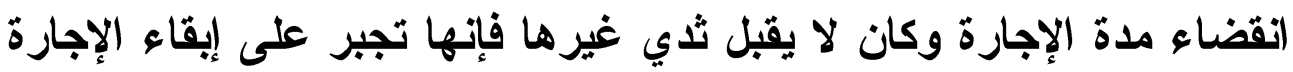

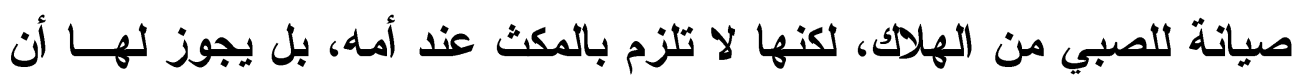
ترضعه في فناء الارار(r).

(1) الثيخ/ أحمد إبراهيم - المستثار واصل علاء - المرجع السابق - صه اه ه - هامش 1.

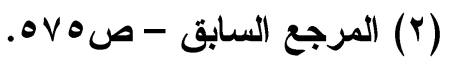




\section{الترقيم الدوله \\ ISSN 2356-9050}

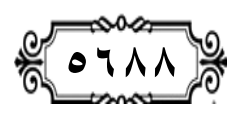

حولية كلية اللفة العربية بجرجا مجلة علمية محكمة

\section{الإطاب الثالث}

\section{أثر الإرضاع في هق الهضانة في الفقه الإسلاهمي والقانون}

أولاً: أثر الإرضاع في هق الهضانة في الفقه الإسلاهي:

قرر علماء الحنفية أن حق الحاضنة في التربية لا يسقطه ولا يؤثر

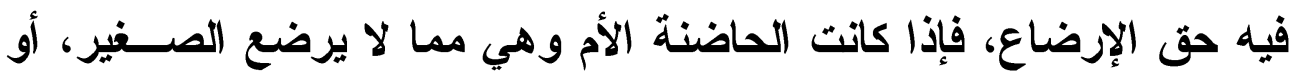

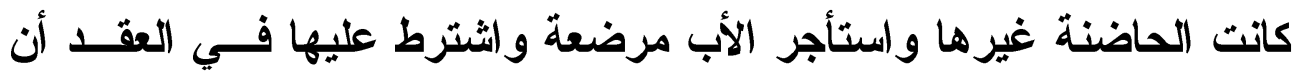
ترضع الصغير عند الأم فإن الثرط ينفذ وتلتزم الظئر بمقتضاه أن تمكث عند

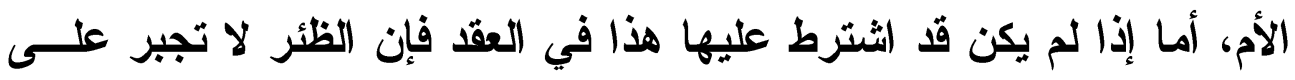
المكث عند الأم، إنما تكون مخيرة في أن تلاخل عند الأم لترضـــع الصــفير

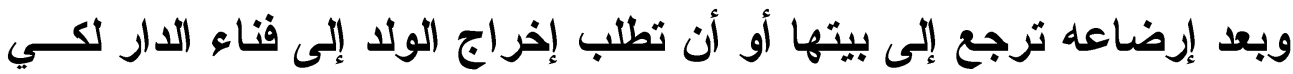

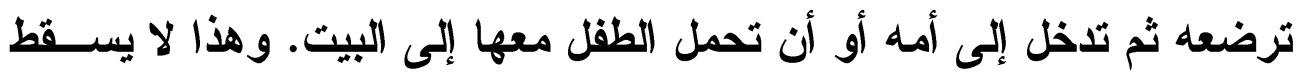
حق الأم في أن تطلب مرضعة ترضع الصغير وهو عندها حالة عـــدم رضــا الأم بخروج ولاها إلى المرضعة في فناء الادار أو الأهاب به إلى بيتهاب(1). ثانيًا: أثر الإرضاع في هق الهضانة في القانون: أخذ القانون بما قرره فقهاء الحنقية في أنه إذا أبت الأم أن تزضع

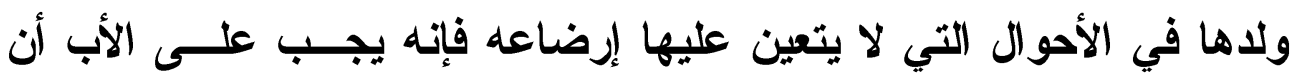

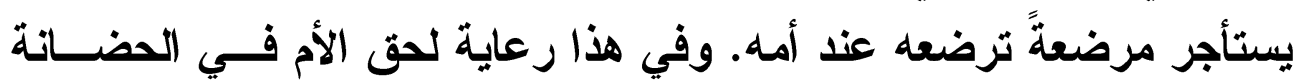

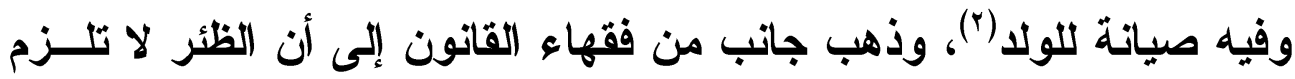
بالمكث عند أمه، بل يجوز لها أن ترضع الصغير في فناء الدار (َ).

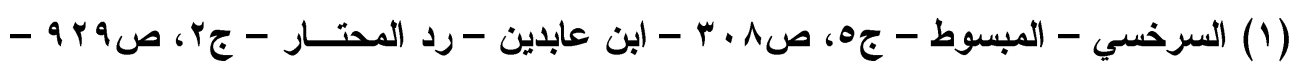

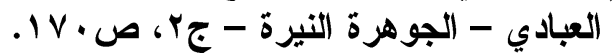

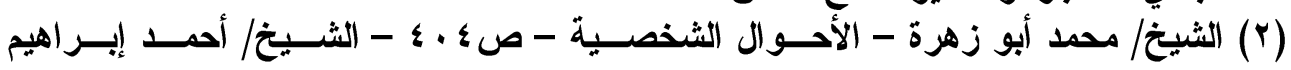

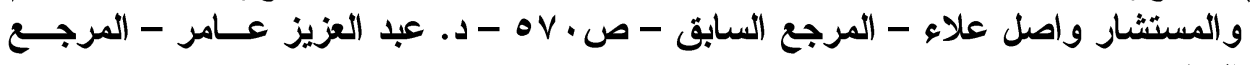

( الثيخ/ أحمد إبر اهيم - المستثار واصل علاء الدين - المرجع السابق - صVY Vr. 


\section{رضاعة المحضون دراسة مقارنة}

\section{فهرس المسادر}

1 - د. هلالي عبد اللاه و د. خالد القاضي - المرجع السابق - صل VI 1 .

r - د. هلالي عبد اللاه و د. خالد القاضي - المرجع السابق - ص99 1 ـ. r- عند إطلاق لفظ الرضاعة فإنه يطلق على ما هو سبب في التحريم وعلى ما هو لازم وحق من حقوق المحضون، وهو محل بحثنا.

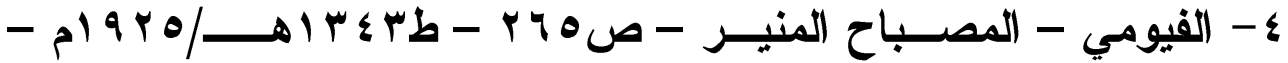

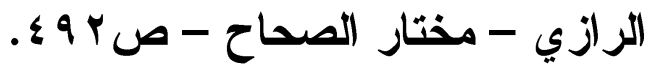

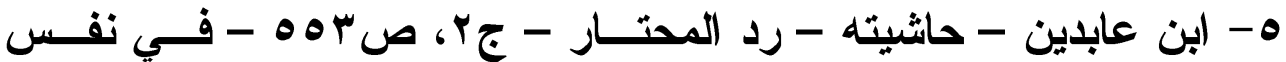
المعنى - الكمال بن الهمام - شرح فتح القدير - جr، ص r. . צ- الكمال بن الهمام- شرح فتح القدير - المرجع السابق - نفس الموضع.

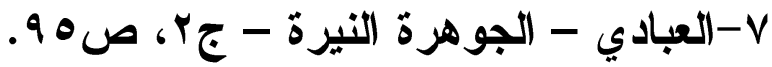

1- الحصكفي - تنوير الأبصار - جه، صعهه - الكمال بـن الهمــام -

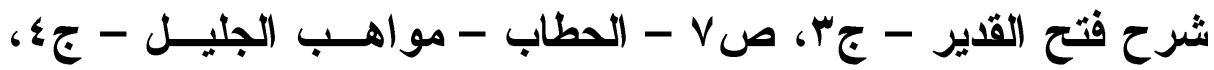

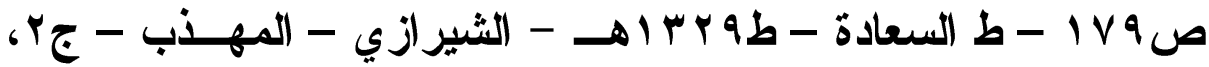
صلو 19 - ط دار الكتب العربية الكبرى - ابن قدامة - المغني - ج9،

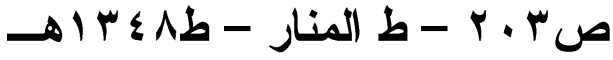

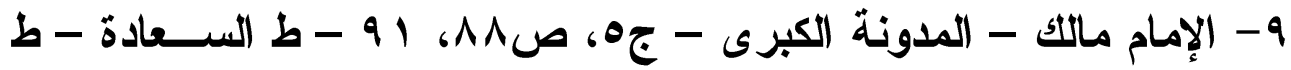
r . 1 - المرغيناني - الهوية على فتح القدير - جب، صهُ. 11 - سورة البقرة - الآية سبr.

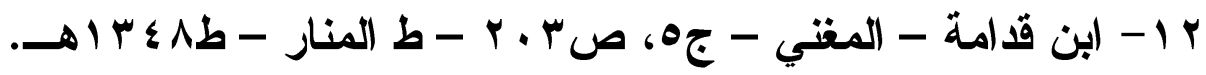

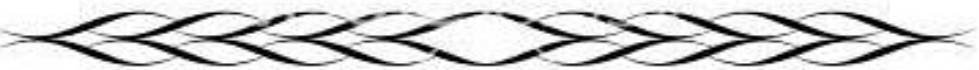




\section{الترقيم الدوله \\ ISSN 2356-9050}

با ا - الحديث أخرجه الطبري في جامع البيان فــي تفســير القــرآن بـرقم

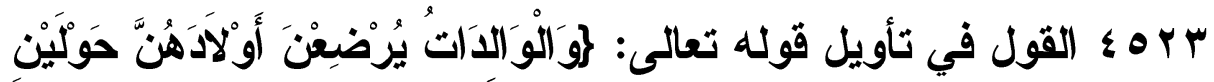
كَامِلَيْنُ\{.

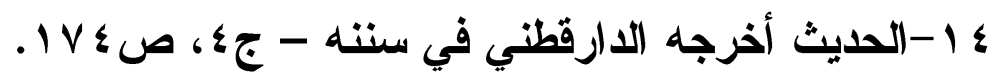

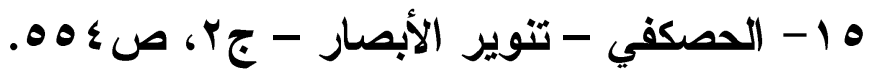

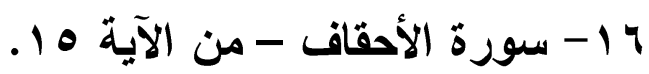
IV 1 1 - ابن قدامة - المغني - الموضع السابق - نفس الموضع.

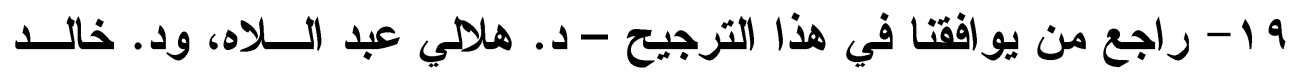

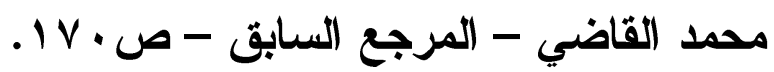

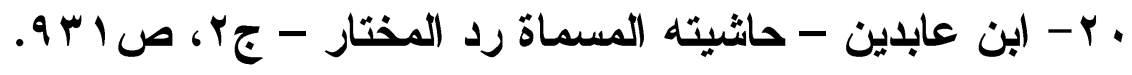

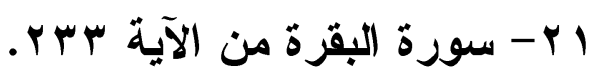

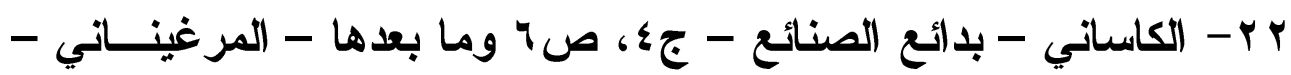

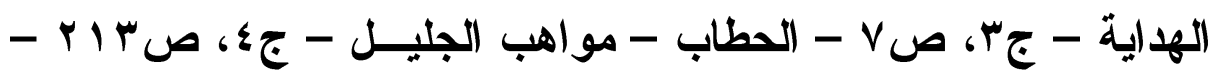

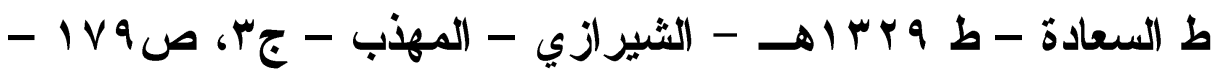

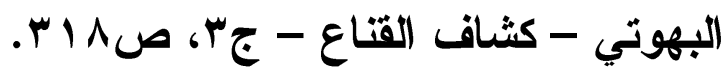

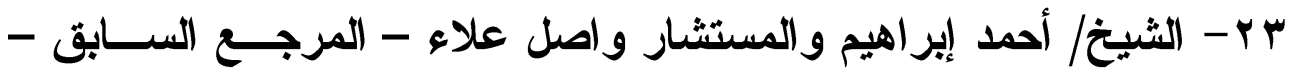

$$
\begin{aligned}
& \text { ص }
\end{aligned}
$$

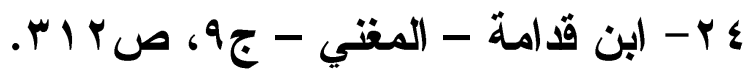

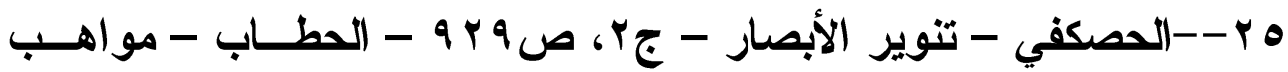

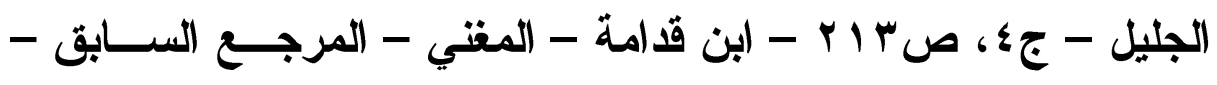

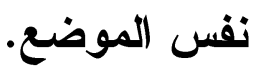

\section{0}




\section{رضاعة المحضون دراسة مقارنة}

צ - ابن عابدين - رد المحتــار - جr، صو r q - الحطــاب - مواهـب

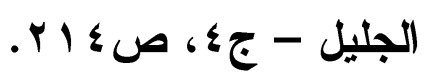

r r - ابن عابدين - المرجع السابق - نفس الموضع.

1 r - ابن عابلين - المرجع الســابق - نفـس الموضــع - الشــيرازي -

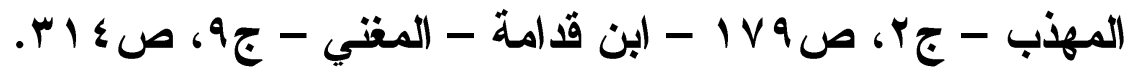
q Y -ابن قدامة - المغني - ج9، ص r اس - الثيرازي - المهذب - نفسس الموضع - الحطاب - مواهب الجليل - جعء، صع ا با. . r- سورة الطلاق - من الآية 7. r r - المراجع السابقة - نفس المواضع - ومــن المعاصــرين - د. عبـــ

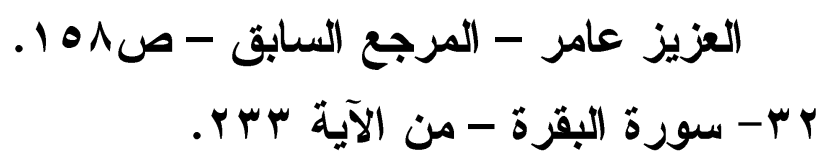
rr- الحطاب - مواهب الجليل - جع، صع اب - الثيرازي - المهذب -

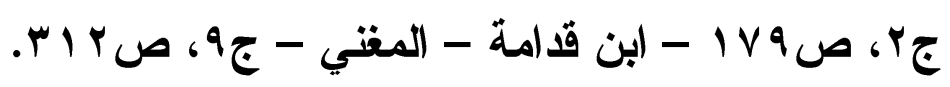
ع ب- الحطاب - مواهب الجليل - نفس الموضع السابق - ابــن قدامــة المغني - نفس الموضع السابق - الألوسـي - روح المعساني - جا، ص V ع - ط الأميرية - ط ا ـ M اهـ - الجصاص - أحكام القرآن ج) ص، صب . ع - ط الأوقاف الإسلامية بالأستانة - طه سب اهــ.

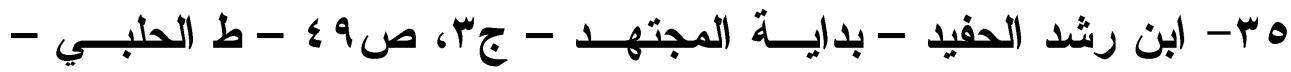
طq r س- سورة البقرة من الآية سبr.

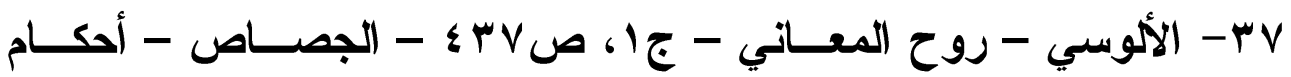

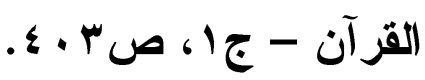

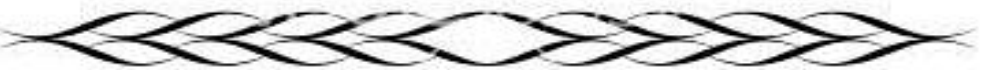




\section{الترقير الدولخ \\ ISSN 2356-9050}

^r- راجع نص المادة (ror ا من قانون الأحوال الشخصية السوري - في نفس المعنى راجع المادة (ع 7) من مشروع القانون العربي الموحـــ ـ وراجع الشيخ/ أحمد إبراهيم والمستشار واصل علاء - المرجع السابق مئ

$$
.1 \mathrm{l} \cdot \omega-
$$

q ب- د. عبد العزيز عامر - المرجع السابق - صهوه 1 ه • ع - في نفس المعنى الثيخ أحمد إبراهيم والمستثـــار واصـلـ عــلاء -

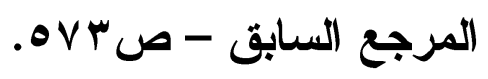

اء -ابن قامة - المغني - ج9، ص اس - ومن فقهاء القانون - د. عبد

$$
\text { العزيز عامر - المرجع السابق - صب آ } 1 \text {. . }
$$

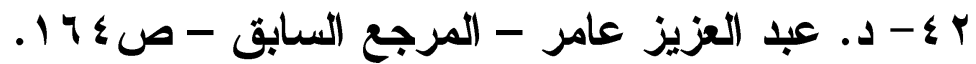

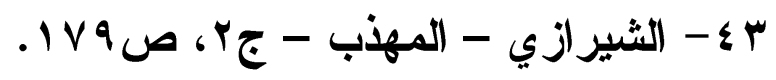

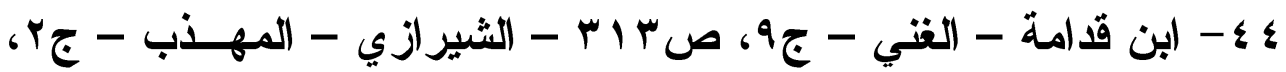
صa Vq - ومن فقهاء القانون د. عبد العزيز عامر - المرجع السابق

$$
.17 \varepsilon v-
$$

هـ - راجع من يوافقنا في هذا الترجيح - د. عبد العزيز - المرجع السابق

$$
\text { - نقس الموضع. }
$$

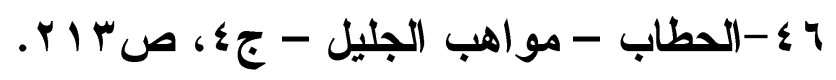

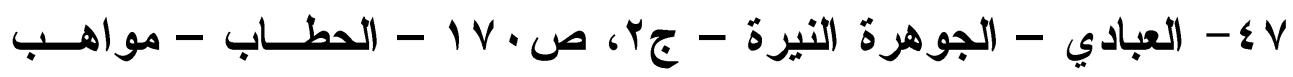

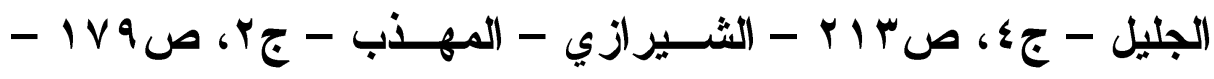

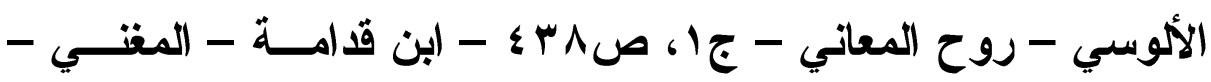

ج9، صب آ - ومن المعاصرين - د. عبد العزيز عامر - المرجـع

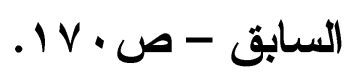

\section{(2)}




\section{رضاعة المحضوز دراسة مقارنة}

$$
\begin{aligned}
& \text { 1 ـ - الثيرازي - المهذب - جr، صو IV9 - ابن قامة - المغني - ج9، } \\
& \text { صץ וr. }
\end{aligned}
$$

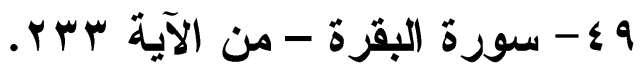

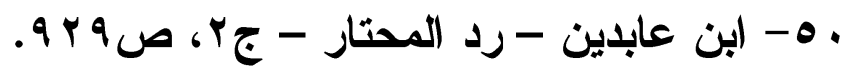

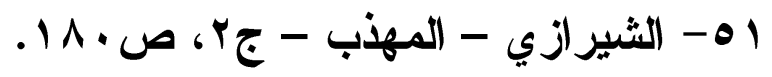

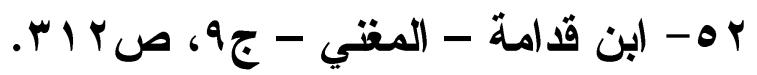

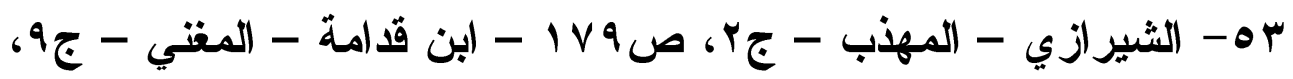

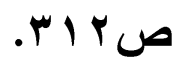

ع - العبادي - الجوهرة النيرة - جr، ص. ب ا ـ - المرغيناني - الهداية -

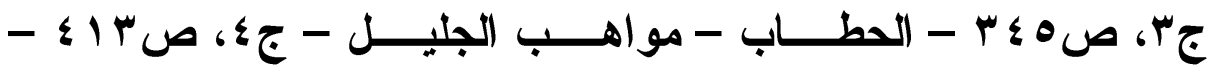
الشيرازي - المهذب - جr، صس اس - ومسـن المعاصــرين الثــيخ/

$$
\text { محمد أبو زهرة - الأحوال الشخصية - ص IV I . . }
$$$$
\text { هـ- العبادي - المرجع السابق - نقس الموضع. }
$$

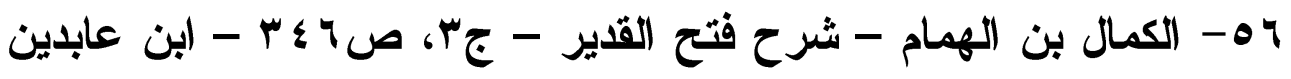
- رد المختار - جr، ص. • هو - ومن المعاصرين - د. عبد العزيــز

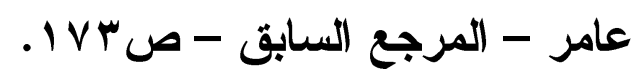

ه - المراجع السابقة المشار إليها في هامش I I.

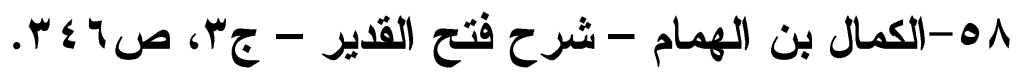
هـ - راجع نص المادة ror or فقرة ثانية من قـانون الأحسـوال الشخصـية

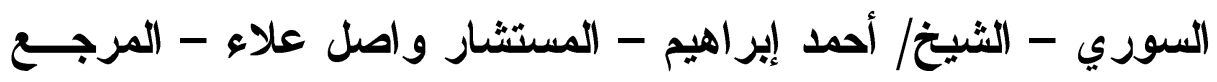

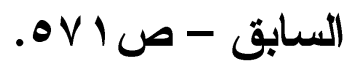




\section{الترقير الدولم \\ ISSN 2356-9050}

ـ - الشيخ/ أحمد إبراهيم والمستشار واصل علاء - المرجــع الســابق -

$$
\begin{aligned}
& \text { ص }
\end{aligned}
$$

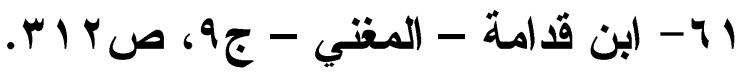

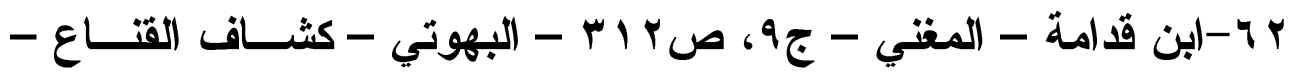

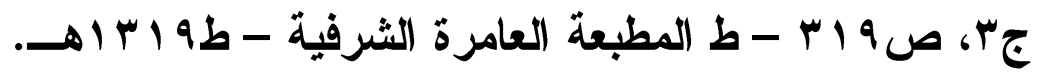

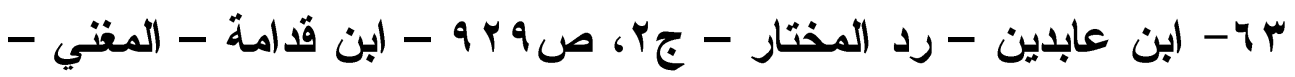
ج9، ص r اس - البهوتي - كثاف القتاع - جr، صو اس - الثــيخ

$$
\text { محمد أبو زهرة - صدع . • ع. }
$$

ع - الثيخ/ أحمد إبراهيم - المستثار واصل علاء - المرجع الســابق -

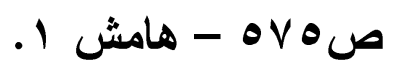

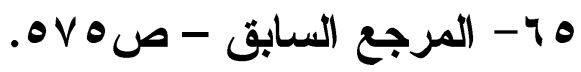

7 السرخسي - المبسوط - جه، صـ • ب - ابن عابدين - رد المحتار -

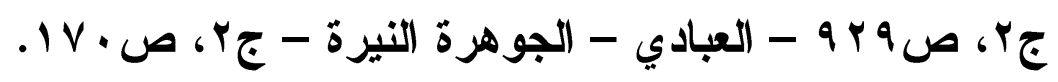

V V - الثيخ/ محمد أبو زهرة - الأحوال الثخصية - صع - ع - الثــيخ/

أحمد إبراهيم والمستشار واصل علاء - المرجع السابق - ص. • -

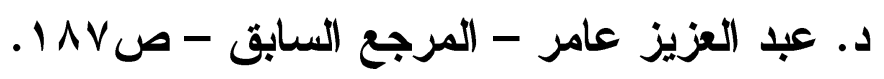

1 - الثيخ/ أحمد إبراهيم - المستثشار واصل عـلاء الــدين - المرجـع

$$
\text { السابق - ص IV }
$$




\section{رضاعة المحضون دراسة مقارنة}

की 0990 ?

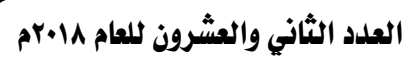
الجزء السادس

فهـوس الاوضوعات

\begin{tabular}{|c|c|c|}
\hline |لصفمة & الإوض & $p$ \\
\hline $077 \%$ & Research Summary & .1 \\
\hline זד & تمهيد وتقسيم &.$Y$ \\
\hline 0770 & المالقانمث الأول: في تعريف الرضـاعة وهـدتها في الفقــه الإسـلاهي & .r \\
\hline 0770 & 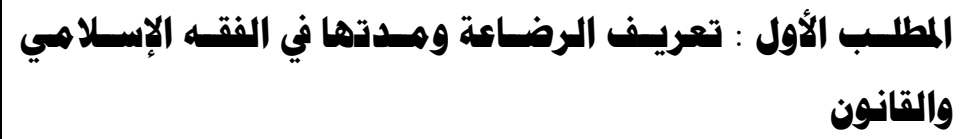 & . $\varepsilon$ \\
\hline $07 V I$ & 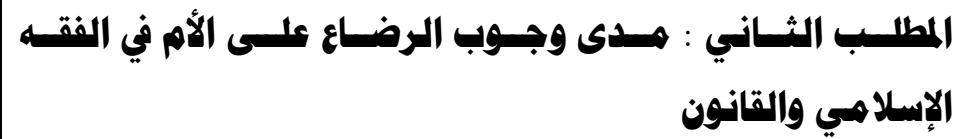 & 0 \\
\hline $07 \vee 9$ & 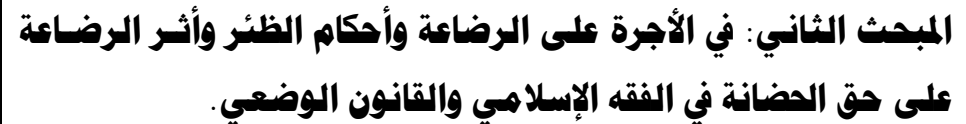 & .7 \\
\hline $07 \vee q$ & المطلب الأول : أحكام الأجرة في الرضاع في الفقه الإسلاهي والقانون &.$V$ \\
\hline$\triangle ૫ \wedge ५$ & المطلب الثاني : أحكام الظئر في الفقه الإسلاهي والقانون &.$\wedge$ \\
\hline$\Delta \neg \wedge \wedge$ & المالقب الثالث : أثر الإرضاع في حق الحضانة في الفقـه الإسـلاهي & 9 \\
\hline $07 \wedge 9$ & فهرس المصادر والمراجع & 1. \\
\hline 0790 & فهرس الموضوعات & 11 \\
\hline
\end{tabular}
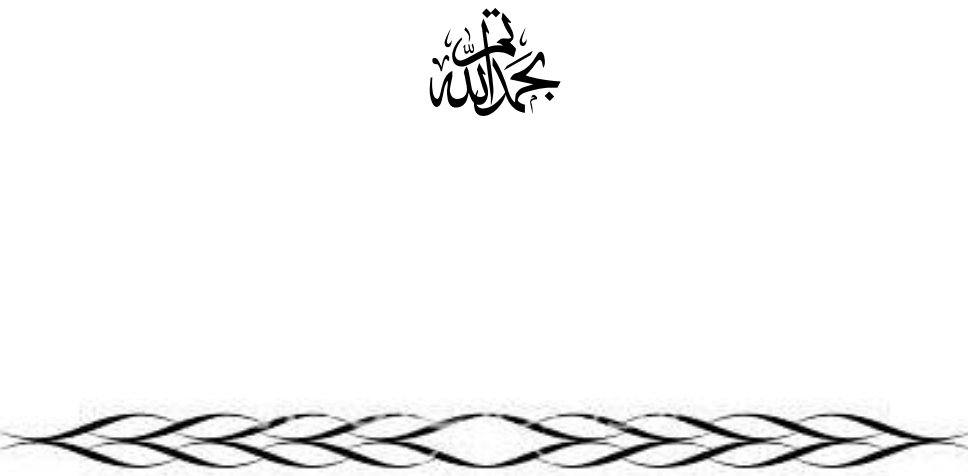